\title{
Do corruption and regulations matter for home country nascent international entrepreneurship?
}

\author{
Farzana Chowdhury ${ }^{1}$. David B. Audretsch ${ }^{2}$
}

Published online: 21 May 2020

(c) The Author(s) 2020

\begin{abstract}
We examine the influence of corruption and regulatory environment on the home country entrepreneurship level. Using data from 54 countries from 2005 to 2011, we find that corruption does not have a consistent negative influence on home country nascent international entrepreneurship. With regards to regulations, administrative regulations have different influence than regulations that have financial implications. Tax related regulations do not have any significant influence in high corrupt countries. The results of our study also show that regulation and corruption interact uniquely with nascent internationals in the home country. The results of our study hold several robustness checks.
\end{abstract}

Keywords International entrepreneurship $\cdot$ Regulation $\cdot$ Tax $\cdot$ Export $\cdot$ Corruption

JEL Classification $\mathrm{H} 0 \cdot \mathrm{M} 13 \cdot \mathrm{M} 16$

\section{Introduction}

Corruption has long been associated with poor economic activity (Aghion et al. 2004; Alesina et al. 2003; Tanzi and Davoodi 2001) and sometimes has been called 'cancer' in society. ${ }^{1}$ Despite the negative influence of corruption on economic activity, it is prevalent in many countries around the world and is an indicator of the institutional environment in a country. The Institutional environment has long been of great interest in both entrepreneurship (Chowdhury et al. 2019; Estrin et al. 2013; McMullen et al. 2008) and international business theory (Cuervo-Cazurra 2008; Cantwell et al. 2010) since home country institutional

${ }_{1}^{1}$ James D. Wofensohn used 'cancel of corruption in his presidential address at the 1996 World Bank/IMF annual meeting.

Farzana Chowdhury

farzana.chowdhury@durham.ac.uk; farza.chowdhury@gmail.com

David B. Audretsch

daudrets@indiana.edu

1 Durham University, Durham, UK

2 School of Public and Environmental Affairs, Indiana University, Bloomington, IN, USA 
environment influences both firms' and entrepreneurs' decisions and behavior (Dunning and Lundan 2008; North 1990). The home country's institutional environment can be very important for the nascent international entrepreneurs since they are faced with the tasks of confronting both the home and host country institutions (Autio et al. 2011; Dimitratos et al. 2012).

Much of the research concerned with IEs has focused on firm performance (Lu and Beamish 2006) e.g., returns on assets and sales (Zahra and Garvis 2000), profits (Qian 2002) or survival (Westhead et al. 2001), export share or export intensity (Fernández and Nieto 2006; Lockett et al. 2008), host country's characteristics such as development level, institutions, political environment, economic openness, etc. and their influence on MNC's internationalization (Meyer et al. 2009). An important gap remains in the literature is how the home country institutional environment affects nascent international entrepreneurs in the home country (Yamakawa et al. 2013). To fill this important gap in the literature we address the following question in this article: Do corruption and regulatory environment of the home country influence the level of home country nascent international entrepreneurship? How do regulatory institutions and corruption interact with each other to influence the level of home country nascent international entrepreneurship (IE)? By addressing these questions, we hope to better understand and recognize that perhaps costs associated with corruption is not monotonic and identify other factors that may influence the cost associated with corruption.

The growing scholarly literature on international entrepreneurship (IE) is concerned with entrepreneurial activity across national borders and its key influencers (Yamakawa et al. 2013; Westhead et al. 2001). In this article, we view nascent IE as the percentage of earlystage entrepreneurs who have customers abroad. Corruption can be an important component for the nascent international entrepreneurship. Navigating institutional context can present a challenge and an opportunity for nascent home country international entrepreneurs. While established international firms also face the same situation, they have more country-specific advantages along with the firm-specific advantage (Erramilli et al. 1997).

The regulatory environment is important to consider since regulations not only can protect entrepreneurial investment (Johnson et al. 2002) but also be a burden on the nascent entrepreneurs (Grilo and Thurik 2005). Extensive regulations have often been cited as reasons for inefficiency and ineffectiveness and lower performance (Bowen and De Clercq 2008).

We contribute to the entrepreneurship and institutions literature by demonstrating that the nature of the institutional environment explains the level of nascent IEs in a country. To test the hypotheses of this paper, we combine both the institutional theory and public choice theory. We test our measure and hypotheses in a global setting by using a sample of 54 countries. Our insights compliments and extend previous studies exploring the interaction between regulations and corruption, underscoring the importance of both regulatory environment and level of corruption. Our findings also provide depth to our understanding of the institutional environment can to influence IE. If the public policy goal is to promote international oriented entrepreneurial activity in a country, regulations that require financial resources can be problematic where corruption is also high.

The remainder of the paper proceeds as follows. In the following section, we present and hypothesize on the links between institutional quality, formal institutions, and IE. In the third section, we describe the variables and methodology. The results of our study are presented next, followed by conclusions and a discussion. 


\section{Theory and hypothesis development}

\subsection{Relationship between Institutions and public choice}

Nascent international entrepreneurs are a unique group and have an interesting relationship with the institutional environment. Institutions play an important role in economic activity by establishing the 'rules of the game' in a society. The rule of the game not only applies to human actions it also influences a firm's behavior by facilitating or constraining certain activity. North (1991, p. 97) defined institutions as "humanly devised constraints that structure political, economic and social interaction" while Scott's (2014, p. 56) definition of an institution is "regulative, normative, and cultural-cognitive elements that together with associated activities and resources, provide stability and meaning to social life". Institutions are composed of both formal and informal institutions. Formal institutions are the written regulations and laws supported and enforced by political structures and regulatory bodies (North 1990; Williamson 2000) they are openly codified, established and communicated by official laws and rules (Helmke and Levitsky 2004). Informal institutions represent non-codified rules which can include cultural and social norms (e.g. corruption) (Baumol 1990; North 1990). Both the formal and informal institutions have influence entrepreneurs' thereby firms' strategic choices (Williamson 2000; Peng et al. 2009). Coyne (2008) defines informal institutions as “... not formally mandated but coexists with formal institutions such as constitutions and written laws" (p. 23). Other scholars have viewed informal institutions as "the old ethos, the hand of the past or the carriers of history" (Pejovich 1999, p. 166) and "have never been consciously designed" (Sugden 1986, p. 54).

Stigler (1971) argued that incumbent firms often promote regulations that serve their interests “... regulation is acquired by the industry and is designed and operated primarily for its benefits" (p. 3). Regulations are established by the existing firms/industry in cooperation with the government authority may be more beneficial for the incumbent firms than the nascent international entrepreneurs. Nascent international entrepreneurs in a home country have to follow the established rules and regulations that may put them at a disadvantage. By engaging in the international activity nascent international entrepreneurs can engage in regulatory arbitrage thereby reducing their reliance and uncertainty associated with home country's weak institutional environment (Berger et al. 2000, Kane 2000, 2009, Carbo et al. 2008).

\subsection{Institutions and international entrepreneurship}

The entrepreneurial activity entails an individual's willingness and capability to pursue the opportunity (McMullen and Shepherd 2006). Expanding to a foreign market presents home country nascent entrepreneurs with an opportunity to grow (Autio et al. 2000; Filatotchev and Piesse 2009; Schwens et al. 2017) while it can also be challenging for them and institutional environment can be an important consideration. Entrepreneurs set-up their organization as well as formulate and modify their strategies and actions based on the environment, they are situated in. It is especially important for international entrepreneurs since they have to adapt “.... firm's operations (strategy, structure, and resource, etc.) to environments" (Calof and Beamish 1995, p. 116) to both home and foreign market environment. Home country nascent entrepreneurs modify their behavior, decisions, and strategic responses based on the institutional environment of both places (DiMaggio and Powell 
1983; Scott 2001). These institutions are crucial for reducing uncertainty along with risk (DiMaggio and Powell 1983; Martens et al. 2007), and entrepreneurial activity (Baumol and Strom 2007; Boettke and Coyne 2003).

\subsection{Linking corruption to nascent international entrepreneurship in home country}

Corruption is an indicator of poor-quality institutions (Tanzi 1998). In many of the emerging and developing economies corruption is so pervasive that it becomes a "norm" "in those countries (Cuervo-Cazurra and Ramamurti 2017; Li et al. 2008; Rodriguez et al. 2005). There is no consistent definition of corruption and hard to define; some defined corruption as the use of public office for private gain (Rose-Ackerman 1999, 2007; Treisman 2000) others define corruption as the unwritten rules and norms that regulate interactions between government officials and clients (Mo 2001; Helmke and Levitsky 2004; Rodriguez et al. 2006). Existing literature shows the conflicting relationship between corruption and entrepreneurship. While corruption has largely been associated with negative effects on economic activity (Glaeser and Saks 2006; Treisman 2000; La Porta et al. 1999; Shleifer and Vishny 1993) and entrepreneurship (Anokhin and Schulze 2009; Bowen and De Clercq 2008) others show a positive relationship (Méon and Weill 2010; Méon and Sekkat 2005).

Nascent international entrepreneurs are situated in a highly corrupt country can either comply with the poor-quality institutions by continuing to pay bribes or to search for alternatives. Existing research suggests that there are five ways that firms respond to their institutional environment-acquiescence, compromise, avoidance, defiance, and manipulation (Oliver 1991). For the nascent international entrepreneurs, avoidance may be more beneficial than the other options since all the other options include either diverting financial resources willingly or taking risks of diverting resources. Defiance could be detrimental since it may result in loss of legitimacy (Oliver 1991) and the ability to attract resources since they are more resources constrained than the established firms (Boddewyn and Brewer 1994; Keefer 1996). Avoidance is associated with "noncompliance", "evasion of outside scrutiny", or "escape from the institutional field", is a way for the international entrepreneurs to avoid the poor-quality institutions in the home country (Witt and Lewin 2007). Both acquiescence and manipulation, involve the use of firm resources thereby increasing cost but might be the best option for the nascent entrepreneurs. Acquiescence is accepting the existence of the poor-quality institution along with the costs associated with it while manipulation also involves using firms' resources to influence the existing institutional environment. While international entrepreneurs have to divert resources that are necessary for the early stage of the venture, they might also be able to use their community networks to negotiate with the government officials. Therefore, combinational of acquiescence and manipulation are the best options for the nascent home country international entrepreneurs.

Nascent international entrepreneurs can use corruption to their advantage to acquire resources or avoid cumbersome regulations by using their internal resources such as home country networks, local knowledge, etc. (Yiu et al. 2007). These entrepreneurs have both tangible and intangible resources. For the nascent international entrepreneurs situated

\footnotetext{
${ }^{2}$ Normative institutions generally take the form of rule of thumb, occupational standards etc. (Scott 2001) and defined as the "rules of procedures that actors employ flexibly and reflexively to assure themselves and those around them that their behavior is reasonable" (DiMaggio and Powell 1991, p. 20).
} 
in corrupt countries, intangible resources might be very valuable. Intangible resources include home country knowledge and network ties. Network ties can be institutional or business ties and both can be used by the home country international entrepreneurs for their advantage (Yiu et al. 2007). Therefore, we hypothesize that

Hypothesis 1 Home country corruption is positively associated with home country nascent international entrepreneurship.

\subsection{Regulatory institutions and nascent international entrepreneurship}

The regulatory environment represents a set of formal institutions in a country, codified, official and play a large role in shaping the environment (Zahra and Garvis 2000; North 1990; Bowen and De Clercq 2008). Regulations and nascent IE have an intertwining relationship. An entrepreneur at the initial stage of the entrepreneurial activity to succeed and gain legitimacy, they would have to comply with the existing regulations related to opening and operating a business (McMullen et al. 2008). These regulations influence level of IE in a country.

Policymakers can also create regulations that can have a positive influence on nascent IE. For instance, policies such as 'Open Door' and 'Go Global' (Hoskisson et al. 2012, p. 2) can be supportive for IE by providing them access to information about different countries along with networking opportunities and access to human and financial capital (Cui and Jiang 2010; Luo et al. 2010; Cumming et al. 2017; Cooper 2003). As nascent international entrepreneurs take advantage of the friendly 'Open Door' policies and expand into a foreign market, they become less reliant on the home country regulations and can gain favorability in the foreign market since some foreign governments will reduce regulatory burden to attract foreign firms. OECD (2002) identified that countries tend to use fiscal and regulatory incentives to attract foreign firms. Fiscal incentives include subsidies, favorable tax rates, and regulatory incentives such as reduction or deviation from normal domestic standards. Based on this, we hypothesize that

Hypothesis 2 The home country's burdensome regulatory environment is positively associated with home country nascent international entrepreneurship.

\subsection{Corruption, regulations, and nascent international entrepreneurship}

Corruption and regulatory environment of a society are important determinants for the level nascent IE of the home country since context influences the entrepreneurs' decisionmaking process. "Grease in the wheels of commerce" theory of corruption suggests that in burdensome regulatory environment corruption can help to avoid impediments imposed by inefficient regulations and increase efficiency (Méon and Weill 2010; Méon and Sekkat 2005).

Corruption and regulatory environment can have a bidirectional relationship. Djankov et al. (2002) study illustrate that corruption and regulations are positively correlated. Another study by World Bank (2003) concluded that heavier regulations are associated with facilitating corruption, weakening rule of law, and government inefficiency. Djankov et al. (2002) study found that the number of procedures required to register a business is much less in developed countries such as Canada than in the developing countries. The regulatory environment can impose a financial burden or an administrative burden that 
can cause delays. While financial burden may incite nascent IEs to use their financial resources to engage in corruption administrative related regulations may lessen that urge as suggested by Barro, "In some circumstances, corruption may be preferable to honest enforcement of bad rules. For example, outcomes may be worse if a regulation that prohibits some useful economic activity is thoroughly enforced rather than circumvented through bribes" (Barro 2000, p. 36). Besides, entrepreneurs positioned in the corrupt environment may have expectation built-in that he/she would have to take on challenges associated with corruption, in another word, entrepreneurs have taken costs and uncertainty already in the cost/benefit calculation. In this situation, even though corruption adds a burden but the benefit of avoiding the burdensome regulations outweighs the cost of corruption, making corruption an attractive mechanism.

Access to information can be another motivation for nascent international entrepreneurs to use corruption to their advantage. Information asymmetry exists between bureaucrats and entrepreneurs, and this information could be useful for nascent IEs. Nascent international entrepreneurs that have political, social, and financial resources can use corruption to gain valuable information from these bureaucrats (Lawton et al. 2014). For those who do not have the extensive political capital or social resources, ${ }^{3}$ corruption enables them to "buy-in" quickly and early on, and to start building resources and gain access to policy influence, discretionary information, and other resources in the long run. This suggests that corruption could benefit nascent IE not only by reducing inefficiency associated with extensive regulations (Méon and Sekkat 2005) but by facilitating access in other ways. Nascent international entrepreneurs can also gain access to bureaucrats to reduce costs by using bureaucrats to use their power to facilitate transactions (Jain 2001) as suggested by Chafuen and Guzman (2000, p. 53) observe that "corruption is the cost of obtaining privileges that only the States can 'legally' grant, such as favoritism in taxation, tariffs, subsidies, loans, government contracting, and regulation" thus corruption could help IE in a country. We thus hypothesize that:

Hypothesis 3 The positive relationship between regulations and home country nascent international entrepreneurship will be strengthened by corruption.

\section{Data and method}

\subsection{Data sources}

We constructed our sample by matching data from the following sources: Global Entrepreneurship Monitor (GEM), World Development Indicators, Doing Business Database, World Governance Indicators, and KPMG. Our dependent variable, nascent international entrepreneurship, comes from GEM, a comparative cross-national database led by London Business School and Babson College, comprising multiple national teams around the world (Estrin et al. 2013; Reynolds et al. 2003). GEM interviews around 2000 individuals in each

\footnotetext{
3 According to the resource-based view perspective, resources are valuable, rare, and difficult to imitate (Barney 1991). Political capital is a specific type of social capital and an important resource that incumbent and established firms developed through political affiliations and informal ties over an extended period. They can use this resource to access information from policy makers (Barney 1991). New firms often lack this important resource.
} 
country. The dataset includes both developed and developing countries. Our explanatory and control variables come from the other datasets mentioned above (World Development Indicator, doingbusiness.org, etc.). Our final dataset is an unbalanced panel data with 54 countries, 171 observations during the period 2005-2011. Table 1 shows the list of countries included in this study.

\subsection{Dependent variables}

We use three measures for our dependent variable, nascent international entrepreneurship, taken from GEM. Nascent international entrepreneurs are a subsample of the total earlystage entrepreneurial activity (TEA), defined as the percentage of the 18-64 population who are either a nascent entrepreneur or owner-manager of a new business that is more than 3 months old, but not more than 42 months (Reynolds et al. 2003; McMullen et al. 2008). We aggregated individual data to the country level. Interviewees were asked "what percentage of their customers come from other countries: 1-25\%, 26-75\%, and 76-100\%. We categorized the responses into three categories: Small, medium, and large IEs. Small nascent international entrepreneurship is measured as a percentage (0 to 100) of entrepreneurial activity (TEA) that indicate that $1-25 \%$ of their customers that live abroad. Medium nascent international entrepreneurship is measured as a percentage of early-stage ventures with 26-75\% of customers that live abroad. Large nascent international entrepreneurship is measured as a percentage of early-stage ventures with 76-100\% of customers that live abroad (Hessels 2008). We used their natural logarithmic form.

\subsection{Independent variables}

Our independent variables came from Doing Business, KPMG, and World Governance Indicators (Djankov et al. 2002; Kaufmann et al. 2009). We used corporate tax, cost of export, time to export, and documents required for export as proxies for the regulatory environment. Corporate taxes measured by the percentage of taxes on profit paid by the business as a percentage of commercial profits obtained from both Doing Business and KPMG (Belitski et al. 2016). Cost of export is the cost associated with all procedures required to export goods and is measured as US dollar per container, time to export reflects the time necessary to comply with all export-related procedures and is measured as days, documents for export reflects the number of documents required per shipment to export goods. All three of these measures are taken from the Doing Business dataset. We used corruption as an indicator of institutional quality. All regulatory environment variables are taken with a 1-year lag to avoid issues of endogeneity between the regulatory environment and nascent international entrepreneurship.

Corruption measures were collected from three different sources-World Governance Indicator (WGI), 'Corruption Perception Index' (CPI) by Transparency International, and Index of Economic Freedom (IEF) by Heritage Foundation. World Governance Indicators reflect the extent to which public power is exercised for private gain, including both petty and grand forms of corruption, as well as "capture" of the state by elites and private interests (Kaufmann et al. 2009). Corruption is calculated by averaging data from 32 existing data sources. Data sources include surveys of households and firms, commercial business information providers, non-governmental information providers, and public-sector organizations. The original score for the indicator ranges from -2.5 to 2.5 (Kaufmann et al. 2009). For convenience, we reversed the order by multiply by -1 , where 2.5 corresponds 
Table 1 List of countries and average of corruption and regulations (2005-2011) Source: World governance indicator, doing business database

\begin{tabular}{|c|c|c|c|c|c|c|}
\hline Country name & $\begin{array}{l}\text { Years } \\
\text { included in } \\
\text { Study }\end{array}$ & Corruption $^{\mathrm{a}}$ & $\begin{array}{l}\text { Number of } \\
\text { export docu- } \\
\text { ments }\end{array}$ & $\begin{array}{l}\text { Time required } \\
\text { to export (days) }\end{array}$ & Tax rate & $\begin{array}{l}\text { Cost to export } \\
\text { (US\$ per } \\
\text { container) }\end{array}$ \\
\hline Argentina & 5 & 0.43 & 6.00 & 14.50 & 109.36 & 1402.50 \\
\hline Australia & 2 & -2.04 & 7.00 & 9.00 & 50.71 & 1018.33 \\
\hline Austria & 1 & -1.83 & 4.00 & 9.50 & 55.33 & 1025.67 \\
\hline Belgium & 5 & -1.38 & 4.00 & 9.00 & 60.11 & 1230.50 \\
\hline $\begin{array}{l}\text { Bosnia and } \\
\text { Herzegovina }\end{array}$ & 4 & 0.32 & 7.67 & 19.50 & 38.91 & 1147.50 \\
\hline Chile & 5 & -1.41 & 5.00 & 17.00 & 25.59 & 695.00 \\
\hline China & 3 & 0.57 & 5.67 & 21.33 & 75.21 & 438.33 \\
\hline Colombia & 5 & 0.24 & 6.00 & 22.33 & 80.80 & 1793.33 \\
\hline Croatia & 5 & -0.02 & 7.00 & 22.33 & 33.20 & 1240.50 \\
\hline Czech Republic & 1 & -0.31 & 6.00 & 17.50 & 49.10 & 965.00 \\
\hline Denmark & 5 & -2.46 & 3.00 & 6.00 & 31.79 & 723.50 \\
\hline Ecuador & 1 & 0.82 & 6.50 & 21.00 & 35.13 & 1327.50 \\
\hline Egypt & 2 & 0.60 & 10.17 & 17.00 & 47.86 & 804.83 \\
\hline Finland & 5 & -2.36 & 5.00 & 9.00 & 47.30 & 522.50 \\
\hline France & 5 & -1.43 & 4.83 & 12.17 & 66.14 & 1260.00 \\
\hline Greece & 1 & -0.11 & 6.00 & 20.00 & 51.20 & 1000.50 \\
\hline Hong Kong & 2 & -1.89 & 3.83 & 8.17 & 24.61 & 558.33 \\
\hline Hungary & 5 & -0.44 & 6.00 & 16.00 & 56.77 & 999.17 \\
\hline Iceland & 4 & -2.18 & 4.00 & 11.33 & 26.97 & 1330.00 \\
\hline India & 2 & 0.43 & 11.00 & 20.50 & 71.71 & 915.50 \\
\hline Ireland & 4 & -1.69 & 2.00 & 8.00 & 26.30 & 1099.50 \\
\hline Italy & 4 & -0.23 & 3.00 & 20.00 & 73.74 & 1276.33 \\
\hline Jamaica & 3 & 0.41 & 7.33 & 19.83 & 51.27 & 1410.00 \\
\hline Japan & 5 & -1.36 & 5.00 & 11.00 & 53.41 & 862.50 \\
\hline Jordan & 1 & -0.25 & 7.83 & 19.33 & 31.23 & 727.50 \\
\hline Kazakhstan & 1 & 0.94 & 12.83 & 86.00 & 39.33 & 2867.50 \\
\hline Korea (South) & 4 & -0.44 & 5.67 & 10.83 & 32.44 & 767.33 \\
\hline Latvia & 5 & -0.20 & 5.67 & 12.50 & 38.29 & 605.00 \\
\hline Macedonia & 2 & 0.22 & 8.50 & 15.00 & 21.89 & 1252.83 \\
\hline Malaysia & 3 & -0.14 & 4.00 & 13.00 & 35.09 & 441.00 \\
\hline Mexico & 3 & 0.30 & 4.00 & 12.83 & 50.24 & 1378.33 \\
\hline Montenegro & 1 & 0.27 & 5.80 & 14.00 & 31.52 & 888.00 \\
\hline Netherlands & 5 & -2.13 & 5.00 & 7.00 & 43.71 & 917.50 \\
\hline Norway & 5 & -2.03 & 5.00 & 8.00 & 42.41 & 861.50 \\
\hline Pakistan & 1 & 0.93 & 8.00 & 23.33 & 38.11 & 643.17 \\
\hline Panama & 2 & 0.32 & 3.00 & 10.00 & 49.63 & 495.50 \\
\hline Peru & 2 & 0.27 & 7.00 & 20.17 & 41.03 & 717.50 \\
\hline Poland & 1 & -0.32 & 4.00 & 17.00 & 43.57 & 859.00 \\
\hline Portugal & 3 & -1.02 & 4.00 & 16.67 & 44.57 & 677.50 \\
\hline Russia & 4 & 0.97 & 12.00 & 24.00 & 53.50 & 1903.33 \\
\hline Saudi Arabia & 2 & 0.13 & 7.33 & 15.67 & 14.59 & 715.17 \\
\hline
\end{tabular}


Table 1 (continued)

\begin{tabular}{|c|c|c|c|c|c|c|}
\hline Country name & $\begin{array}{l}\text { Years } \\
\text { included in } \\
\text { Study }\end{array}$ & Corruption $^{\mathrm{a}}$ & $\begin{array}{l}\text { Number of } \\
\text { export docu- } \\
\text { ments }\end{array}$ & $\begin{array}{l}\text { Time required } \\
\text { to export (days) }\end{array}$ & Tax rate & $\begin{array}{l}\text { Cost to export } \\
\text { (US\$ per } \\
\text { container) }\end{array}$ \\
\hline Slovak Republic & 1 & -0.31 & 6.00 & 20.83 & 48.90 & 1244.17 \\
\hline Slovenia & 5 & -0.94 & 7.00 & 19.83 & 38.31 & 962.17 \\
\hline Spain & 5 & -1.08 & 4.83 & 10.00 & 59.77 & 1143.83 \\
\hline Sweden & 3 & -2.22 & 3.00 & 9.00 & 54.74 & 649.00 \\
\hline Switzerland & 4 & -2.11 & 4.00 & 8.00 & 28.89 & 1387.50 \\
\hline Thailand & 2 & 0.30 & 8.00 & 17.83 & 37.91 & 697.67 \\
\hline Tunisia & 2 & 0.13 & 6.00 & 14.67 & 60.97 & 719.83 \\
\hline Turkey & 3 & -0.04 & 9.67 & 15.67 & 47.40 & 868.50 \\
\hline Uganda & 2 & 0.84 & 13.33 & 35.33 & 35.80 & 2350.00 \\
\hline United Kingdom & 5 & -1.69 & 4.00 & 9.67 & 35.90 & 1021.67 \\
\hline $\begin{array}{l}\text { United States of } \\
\text { America }\end{array}$ & 4 & -1.34 & 5.00 & 6.00 & 46.07 & 995.00 \\
\hline Uruguay & 5 & -1.15 & 7.00 & 20.50 & 52.71 & 1012.50 \\
\hline Venezuela & 1 & 1.08 & 10.17 & 43.00 & 54.19 & 1870.00 \\
\hline
\end{tabular}

${ }^{\text {a }}$ The inverted score for the indicator ranges from negative 2.5 - no corruption to positive 2.5 - severe corruption (Kaufmann et al. 2009)

to high corruption and -2.5 corresponds to low corruption. We also reversed the order for both the Transparency International's 'Corruption Perception Index' (CPI) and Heritage Foundation's IEF's corruption measures. Higher scores in these measures reflect a high level of corruption and lower scores mean low corruption (McMullen et al. 2008). All three measures of corruption are highly correlated, ranging from 0.96 to 0.97 , suggesting that each conceptualization of corruption is quite consistent with the others. ${ }^{4}$

\subsection{Control variables}

To account for the economic development of a country, we use GDP per capita data from the World Development Indicator. Economic development is measured as GDP per capita for the country (Carree et al. 2002). This is important because the level of development can increase entrepreneurial activity in a country. Higher levels of income and economic development could lead to demand for market expansion and more opportunity, and potential entrepreneurs will decide to act. Human capital is measured by the tertiary school gross enrollment ratio and reflects the quality of labor international entrepreneurs may be able to access (Fritsch and Schroeter 2011). Countries with a higher level of human capital tend to exhibit more entrepreneurial activity (Davidsson and Honig 2003). Economic openness reflects the sum of exports and imports of goods and services as a share of gross domestic product (McMullen et al. 2008). Countries with open trade policies likely to have more entrepreneurial activity (McMullen et al. 2008). The manufacturing sector refers to the

\footnotetext{
${ }^{4}$ Data was not available for all the countries every year. We calculated the mean from the available years and used it to replace the missing values (Kim and Li 2014).
} 
net output produced by all producers as a percent of GDP. All measures are taken from the World Development Indicators. To account for the overall business environment of the country, we have included insolvency cost, defined as measured as the cost to close a business (Klapper et al. 2006), and taken from the Doing Business database. Government size is measured by government expenditures as a percentage of GDP. Expenditures include both consumption and transfers. Data are taken from the Economic Freedom Index, as with McMullen et al. (2008). Table 2 presents variables and sources in greater detail.

Descriptive statistics and correlations of all the variables are reported in Table 3. All three corruption measures are highly correlated: Corruption-WGI and Corruption-TI have a correlation of 0.97 and Corruption-IEF and Corruption-WGI have a correlation coefficient of 0.97 . These high correlations reflect the external validity of these measures. Documents required for export and time required are correlated at 0.64, suggesting extensive documentation requirements are associated with delayed processing and extended wait for trade-related activity. Document requirements for export and all three corruption measures have correlations between 0.63 to 0.65 , and time to export and all three corruption measures have correlations from 0.58 to 0.61 .

\subsection{Empirical strategy}

We use the following econometric model to test our hypotheses with panel data:

$$
y_{i t}=f\left(\beta x_{i t-1}, k z_{i t-1}, \epsilon_{i t-1}\right), \quad \mathrm{i}=1, \ldots, \mathrm{N} ; \mathrm{t}=1, \ldots, \mathrm{T}
$$

where $_{i t}$ is nascent IE (Small international entrepreneurship, medium international entrepreneurship, large international entrepreneurship) in a given country $i$ at time $t, \beta$ and $\mathrm{k}$ are parameters to be estimated, $\mathrm{x}_{i t-1}$ is a vector of independent explanatory variables including corruption and regulatory measures and $\mathrm{z}_{i t}$ is a vector of strictly exogenous control variables. Our panel data application utilizes a one-way error component model for the disturbances, with

$$
u_{i, t}=\mu_{i}+\varepsilon_{i, t}
$$

where $\mu_{i}$ denotes the unobservable country-specific effect when we control for the timeinvariant part of unobserved heterogeneity in countries. We used country fixed effects regression with country clustered standard errors.

\section{Results}

Results related to direct effects are presented in Table 7 in Appendix. Table 4 presents results from the interactions related to corruption and regulations. All of our control variables show unsurprising results, with different degrees of significance. Human capital and economic openness are positively related to IE firms (Davidsson and Honig 2003; Carree et al. 2002). Government size and insolvency cost continue to be negatively related to nascent IEs of all sizes as expected (McMullen et al. 2008).

In hypothesis 1 , we predicted that corruption will have a positive relationship with IE. We find support for our hypothesis. In all the specifications, corruption is positively related to all IE and in some instances, it is significant (Specifications 2, 5, 14, and 15) $(p<0.05)$. This supports a greasing the wheels (Méon and Weill 2010; Méon and Sekkat 2005) effect, 


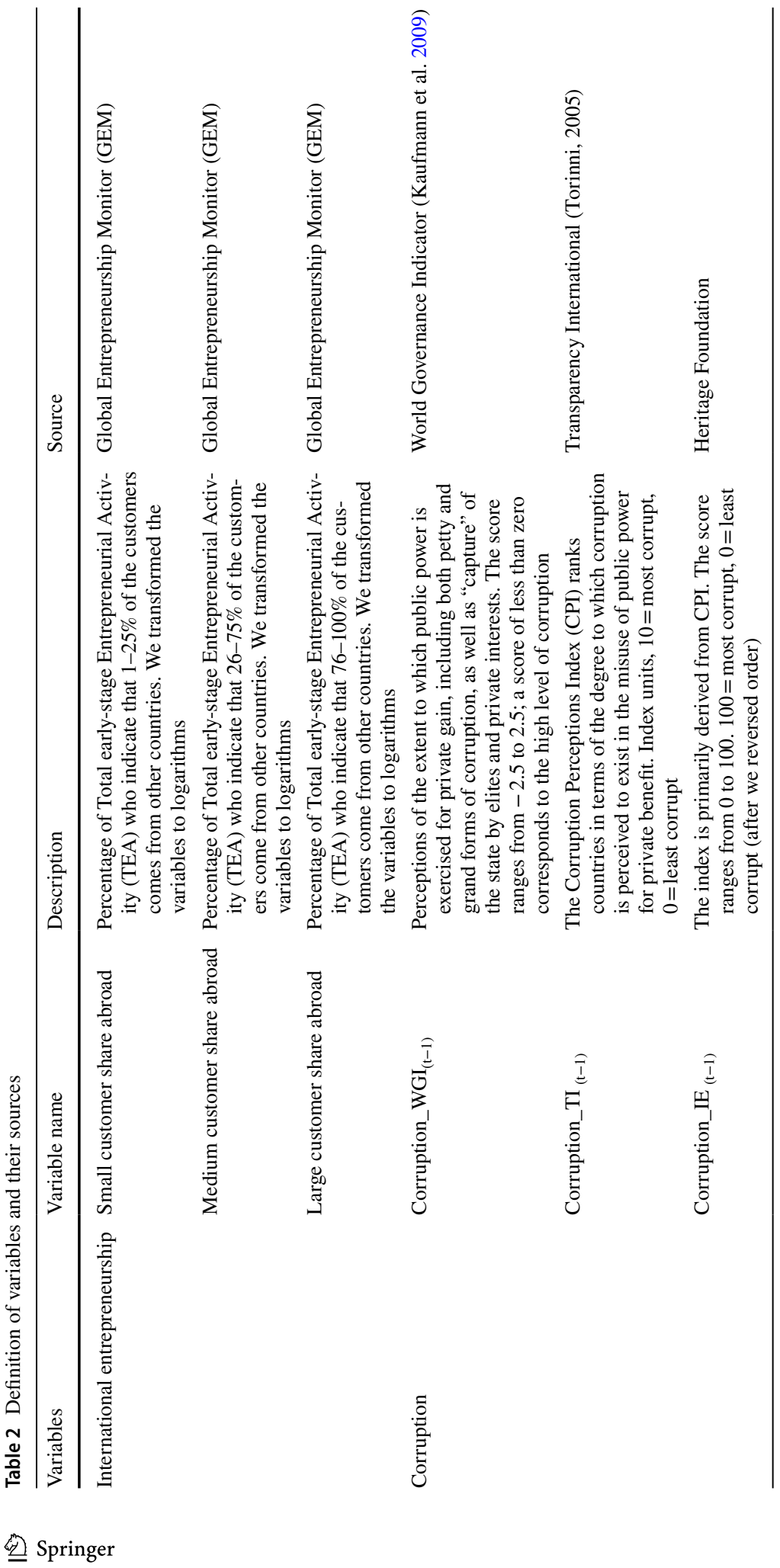




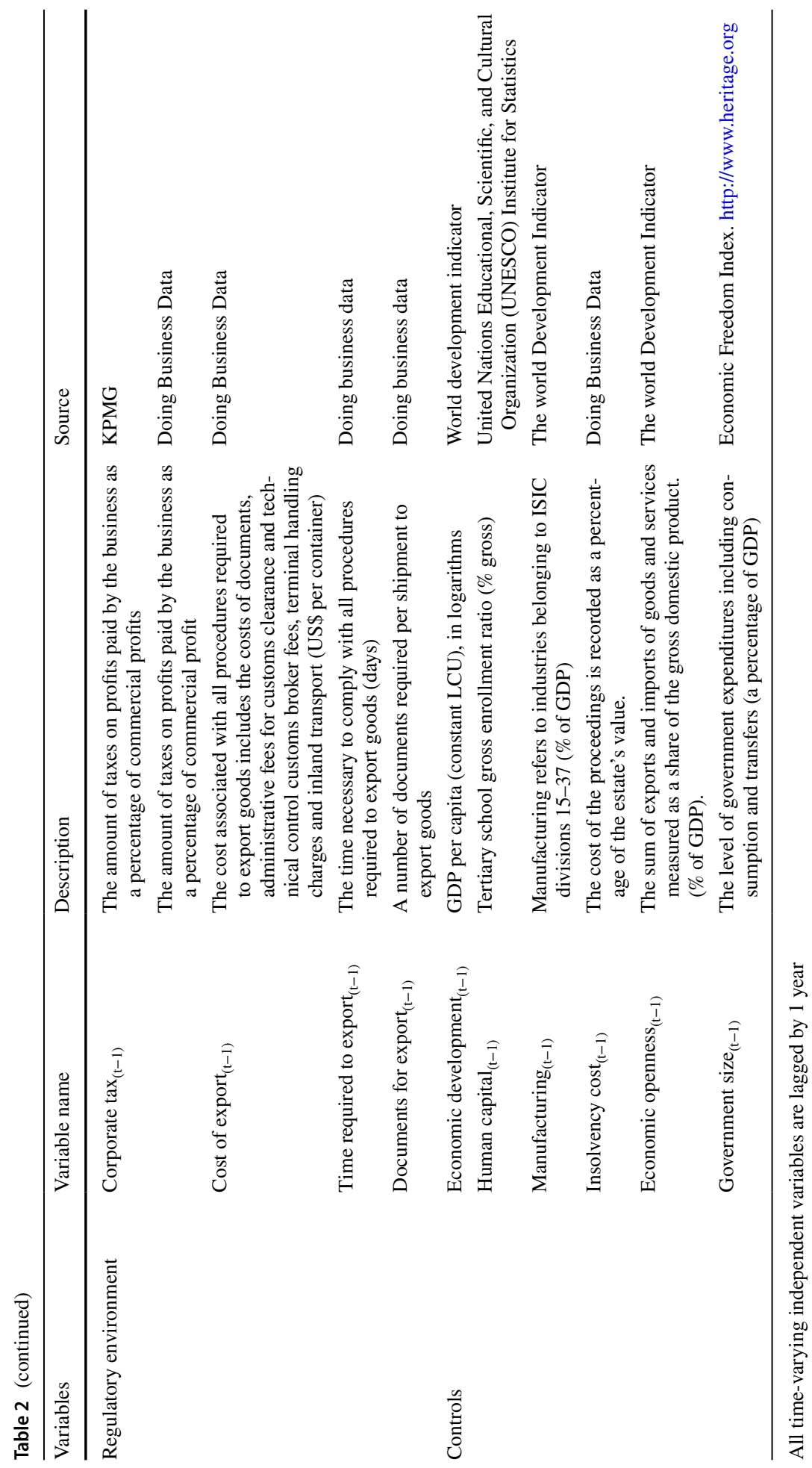




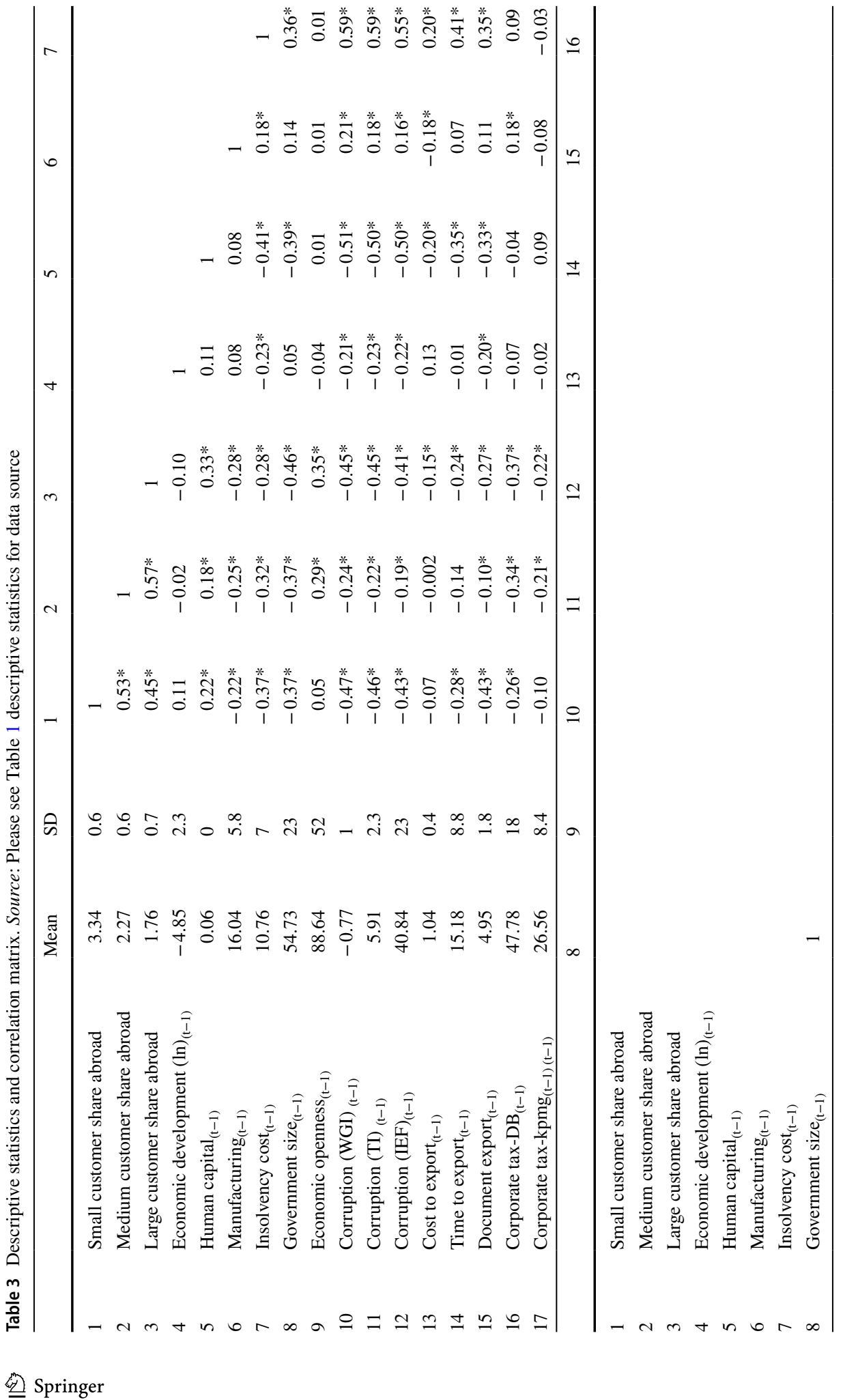




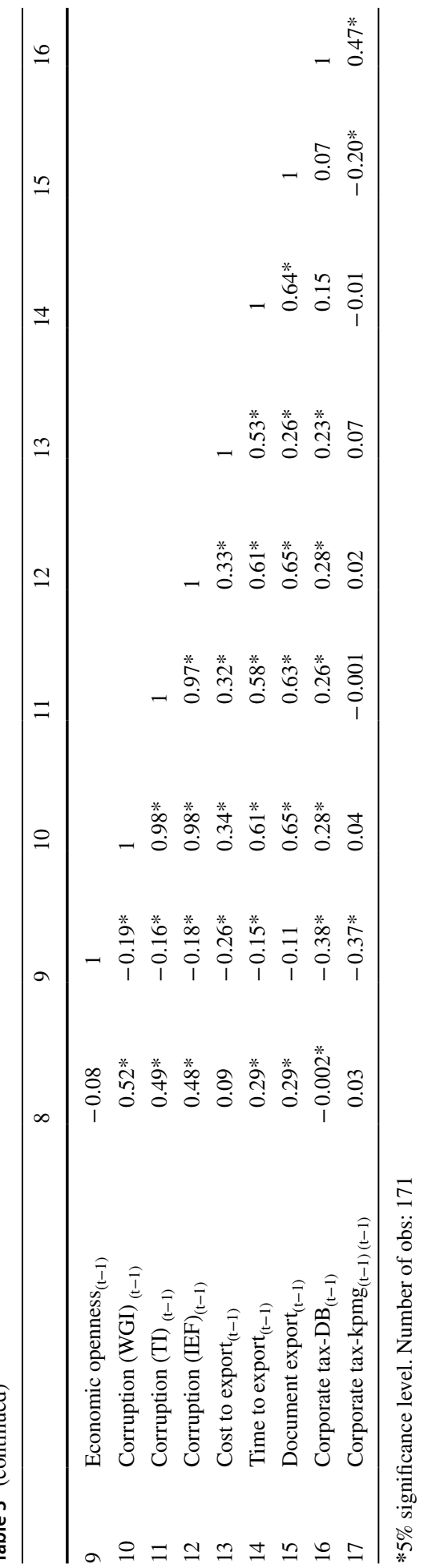




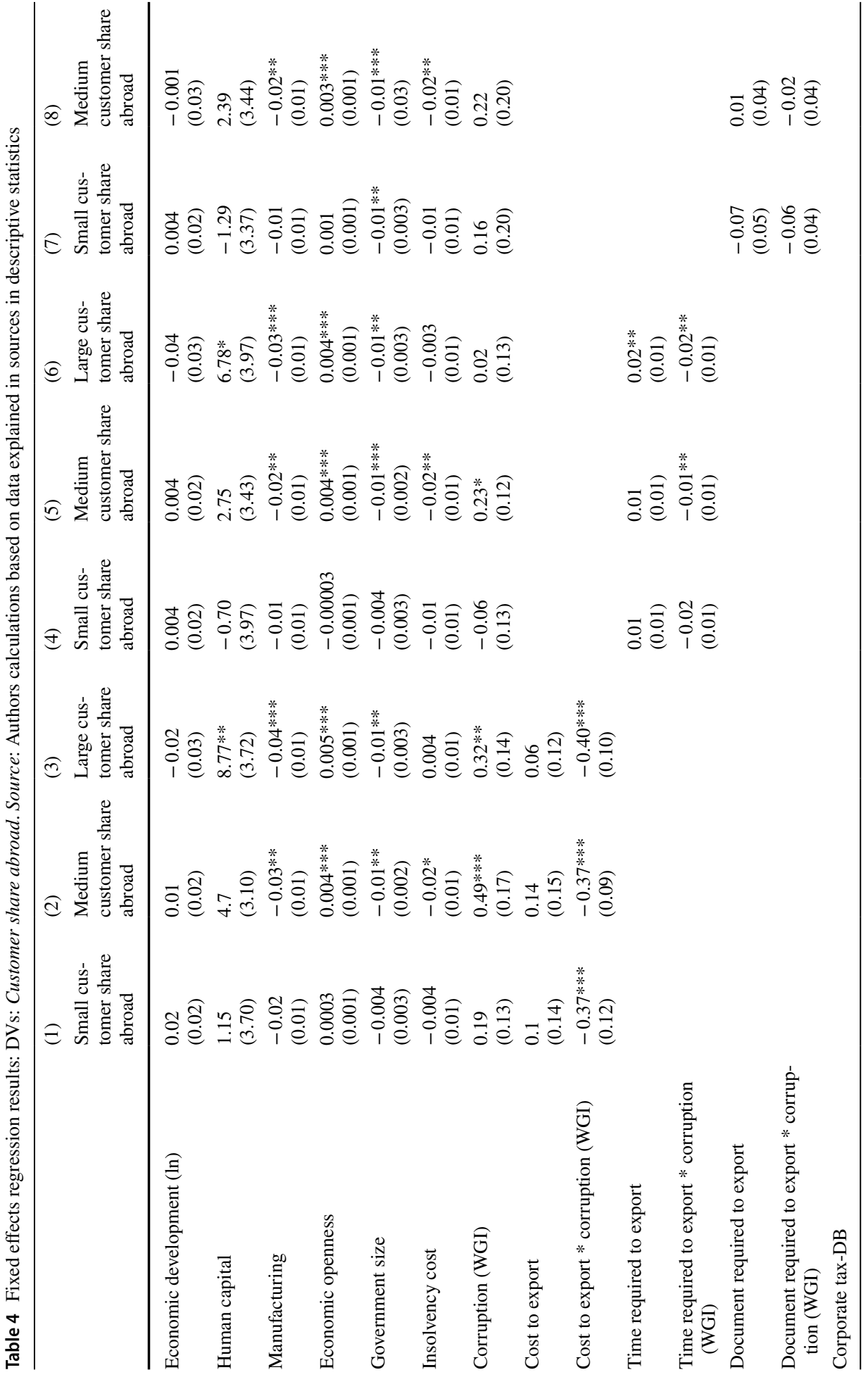




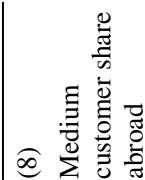

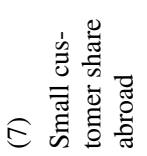

章

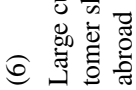

䒕

๙

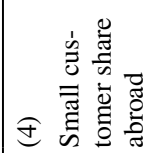

宅

仓ิ

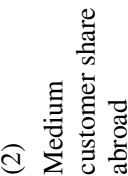

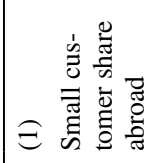

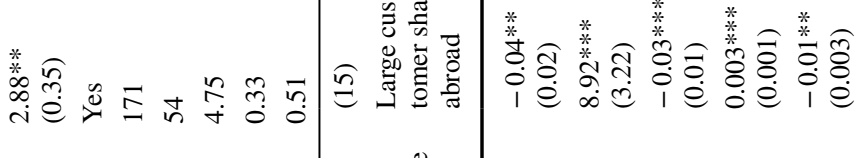

尊

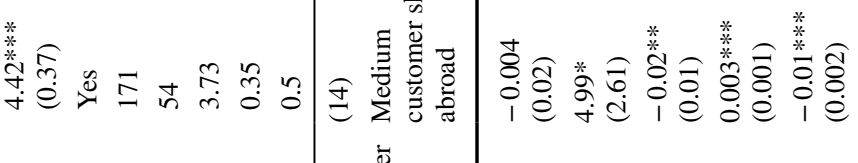

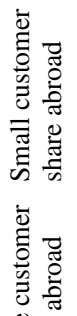

\section{*}

范

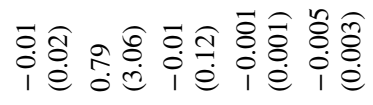
敢

菜命

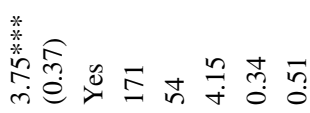

코

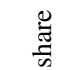

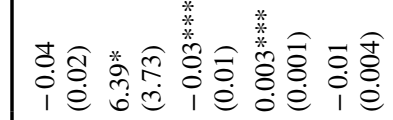

萨导

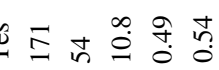

离

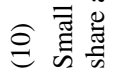

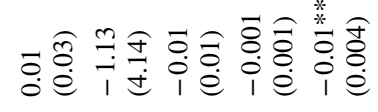

*ैa

离

○ิ

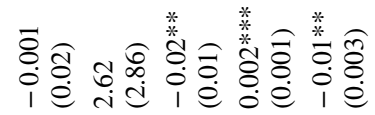

菜字

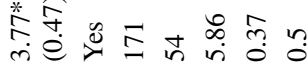

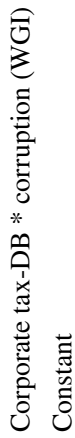

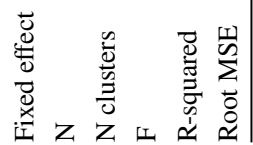

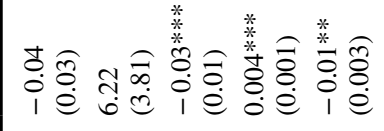

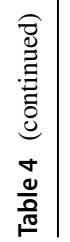




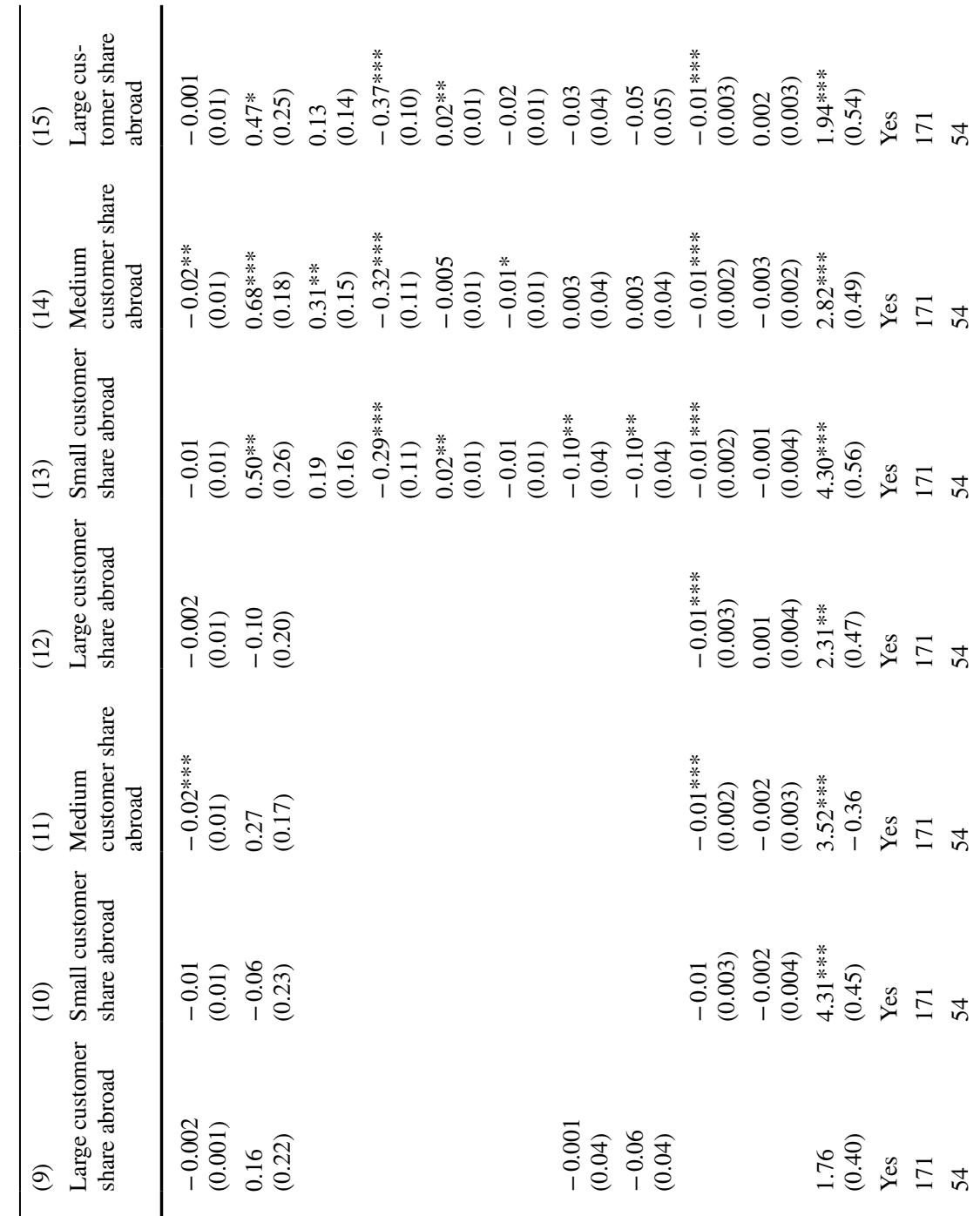

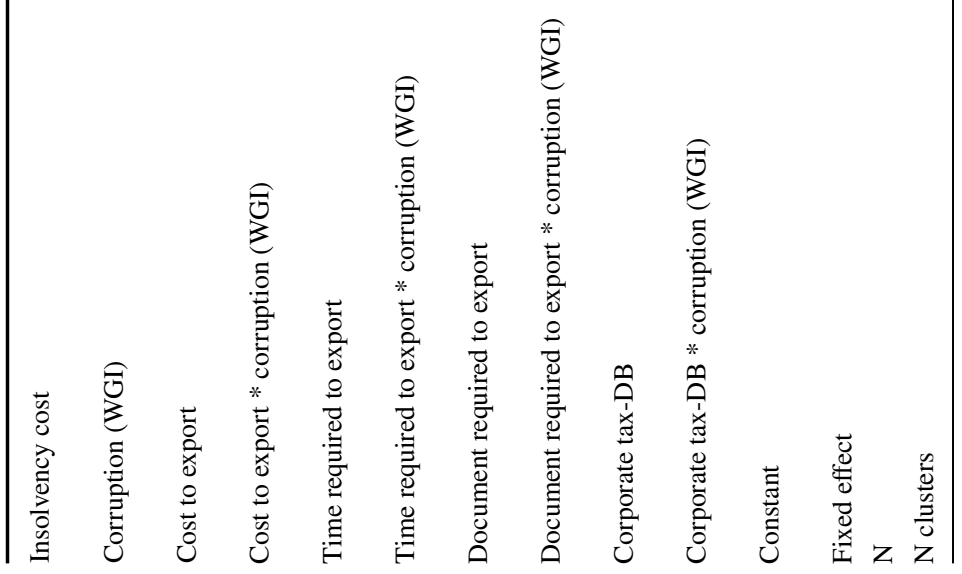




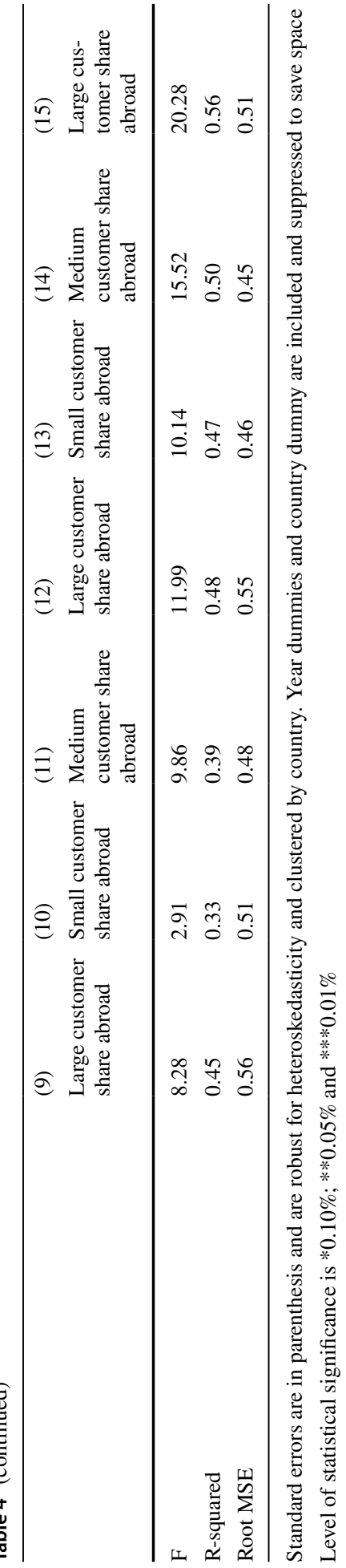


suggesting corruption plays an important role in nascent IE. Besides, medium nascent IE have a stronger positive relationship with corruption than small and large nascent IE.

In hypothesis 2 , we predicted that a complex regulatory environment will have a positive relationship with nascent IE. We find conflicting results. While regulations related to cost and time have a positive relationship with nascent IE. Regulations related to document requirement does not have any significant relationship. We find partial support for our hypothesis. This result suggests that not all types of regulations have a similar effect on IEs, rather a nature of the regulation is an important component.

In hypothesis 3, we posited that corruption will have a stronger impact on the positive relationship between regulations that have financial implications and nascent international entrepreneurship. In specifications 1, 2, and 3 we included the cost to export and the interaction with corruption for small, medium, and large nascent IE. The cost to export is not significant for any IE regardless of their size, but the interaction coefficient is negative and statistically significant $(\beta=-0.37, p<0.01)$ for small IEs and consistent for the medium, and large IE $(\beta=-0.37, p<0.01 ; \beta=-0.40, p<0.01$, respectively) presented in specification 2 and 3 , respectively. The results suggest that regulations that have financial implications combined with corruption become a burden on nascent IE regardless of their size. On the other hand, regulations such as the time required for export is positive but not significant for nascent IE firms of any size. However, when we interacted corruption with the time required for export, it becomes negative and not significant for small and medium types of IEs (specifications 4,5$)$ and significant only for large IE $(\beta=-0.02, p<0.05$; specification 6). Regulations related to the documentation requirement is not significant for all nascent IEs. The results demonstrate the differential impact of regulations on different types of nascent IEs.

Concerning corporate taxes, it has a consistently negative impact on all IEs with various degrees of significance. The relationship is significant for medium and large IEs $(\beta=-0.01, p<0.01 ; \beta=-0.01, p<0.01$, respectively). When we interact with corporate tax rates with corruption, the relationship becomes not significant, but the negative relationship persists (Specifications 10, 11, 12). The result suggest that tax related regulations are not a significant factor for international entrepreneurs. Specifications 13, 14, and 15 present the results of the full model. The interaction of cost to export and corruption is negative and statistically significant for all three types of nascent IE ( $\beta=-0.29$ to -0.37 , $p<0.01)$. The results reflect the added cost of corruption and confirm the 'sanding' effect of corruption (Anokhin and Schulze 2009).

Our original results for the cost of export and corporate tax remain negative for all three types of IE firms. The original results for the cost of export and corporate tax remain negative. Concerning taxes and corruption, the result is only significant for small IE ( $\beta=-0.10$, $p<0.05)$. We find partial support for our hypothesis 3 that the benefit of corruption depends on the types of regulations and the size of the nascent IE. While small nascent IE are negatively affected by the home country corruption, medium and large nascent IEs benefit from corruption depending on the types of regulations. 


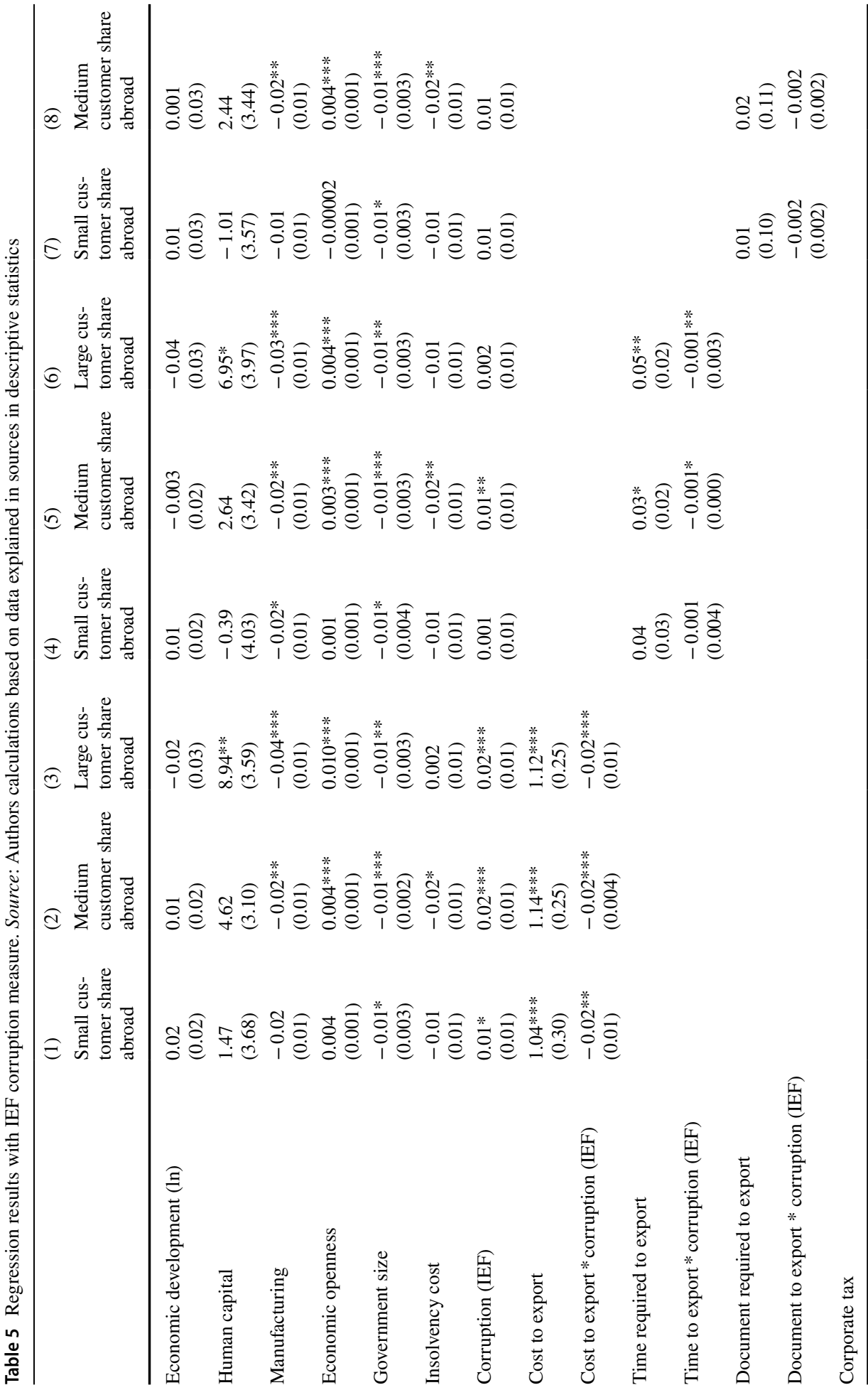




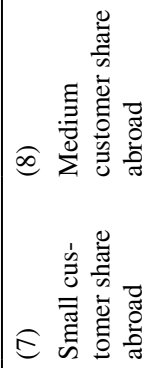

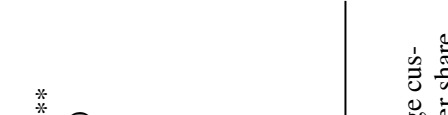

章

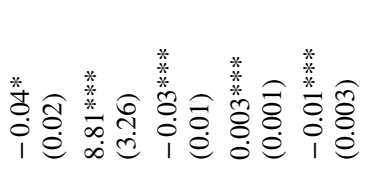

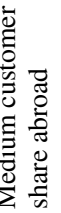

齐 需

e

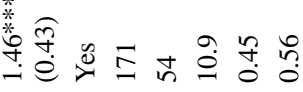

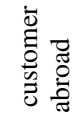

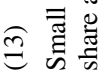

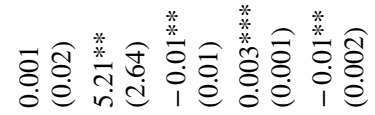

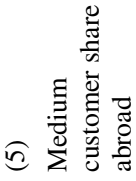

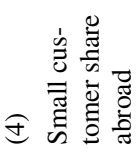

*

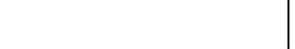

î

E

离

ฮิ

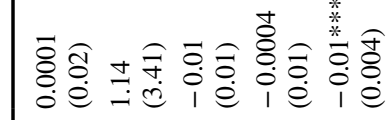

ठิ

ลิ

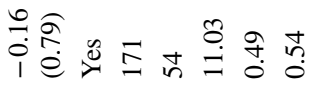

क्ष

害

(ิ) $\sum^{\infty} \overline{0}$

तิ

:

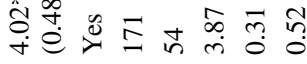

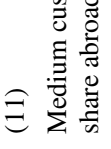

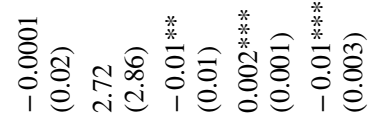

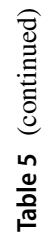

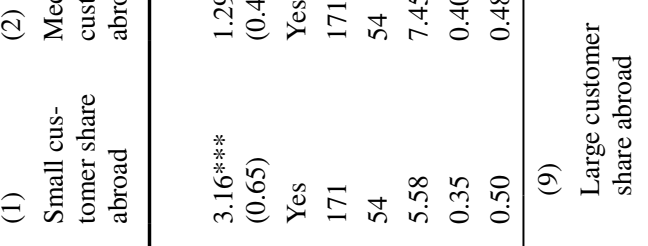

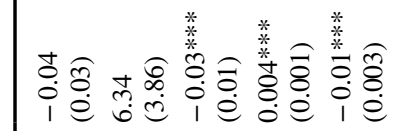

|

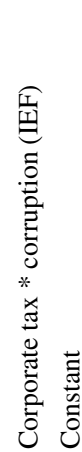

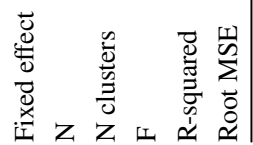

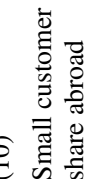

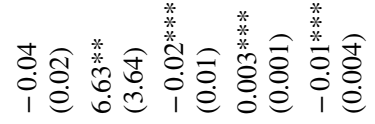

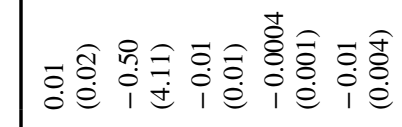

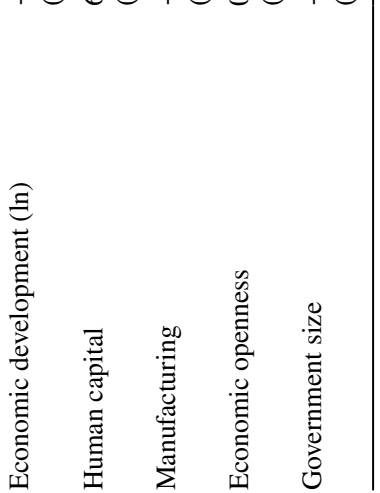




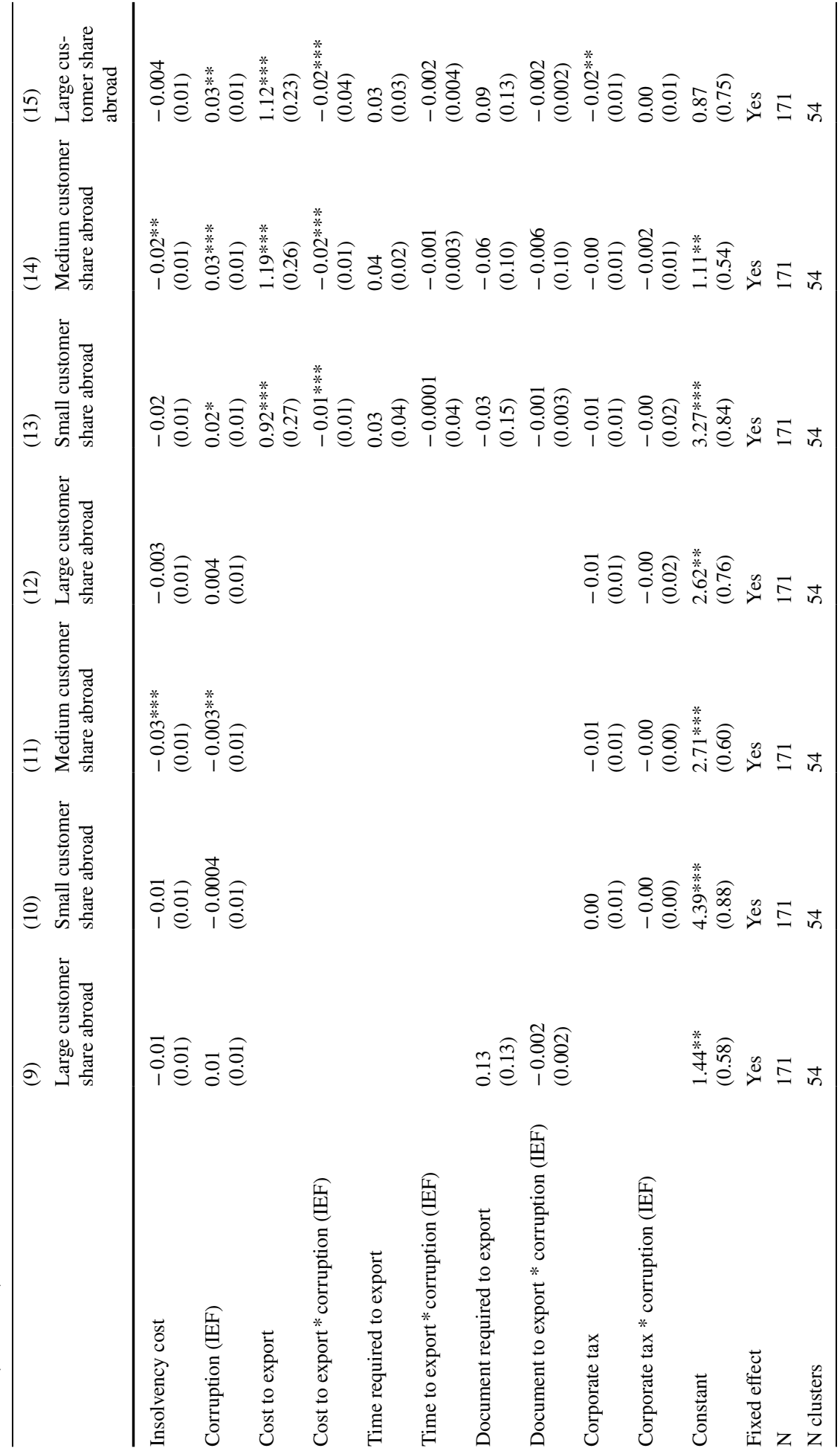




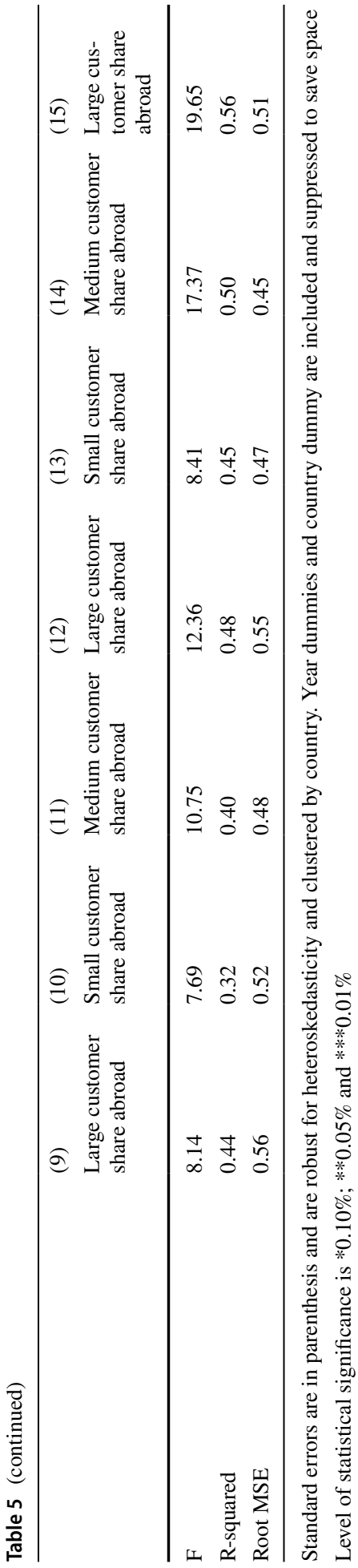

Springer 


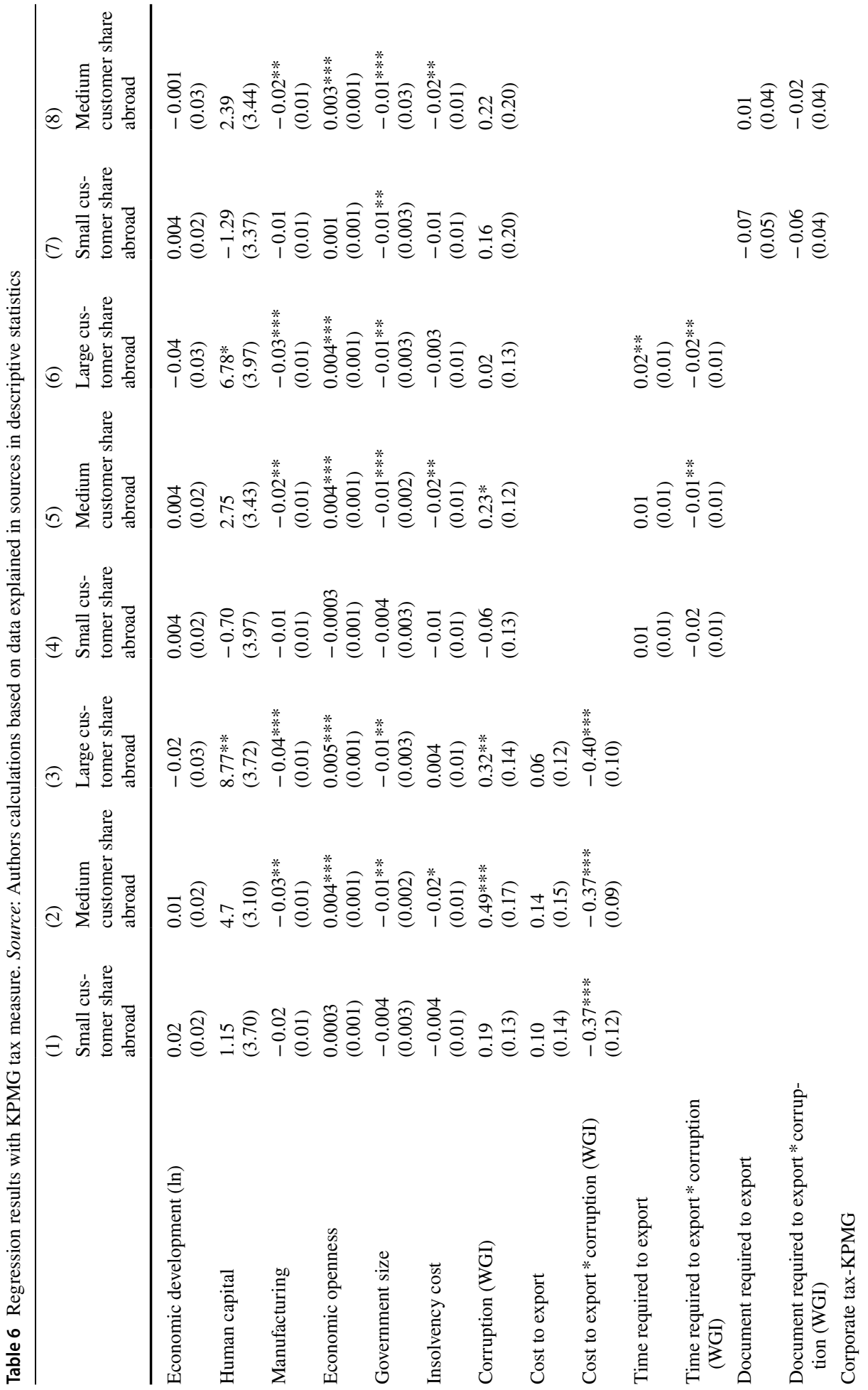


ف

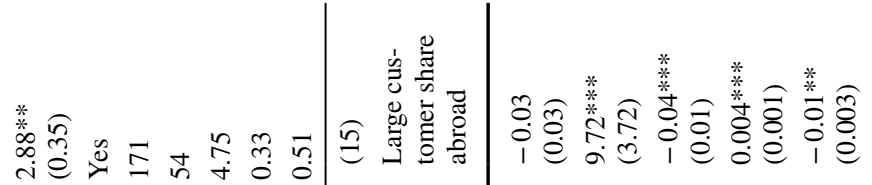

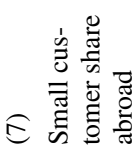

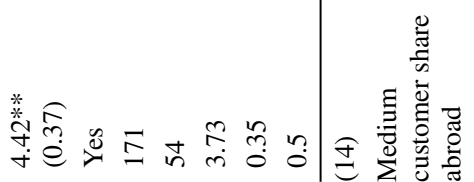

咅

类

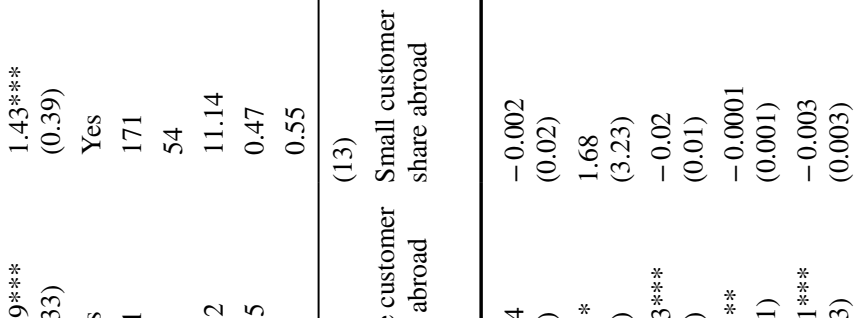

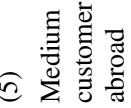

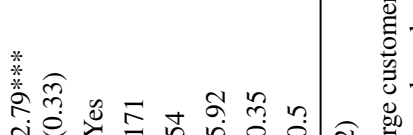

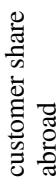

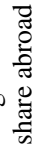

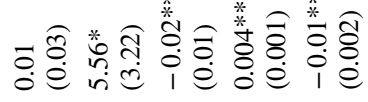

हे

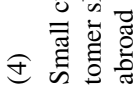

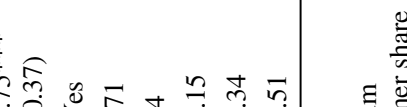

突

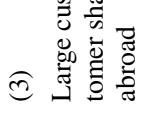

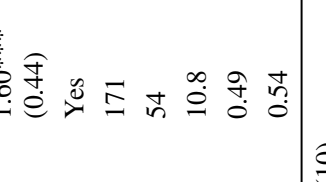

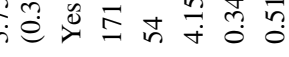

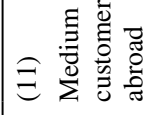

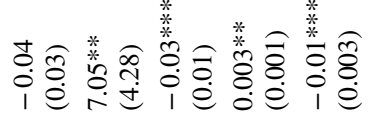

卷

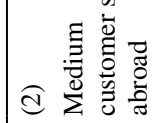

to

离

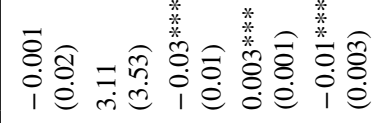

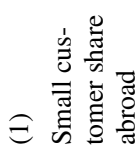

莳矛

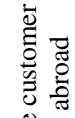

○ิ

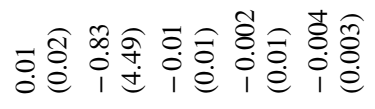

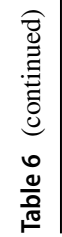

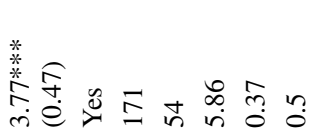

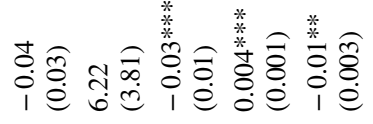

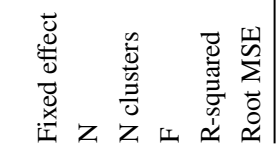

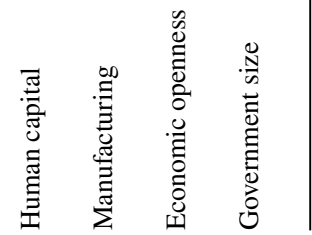




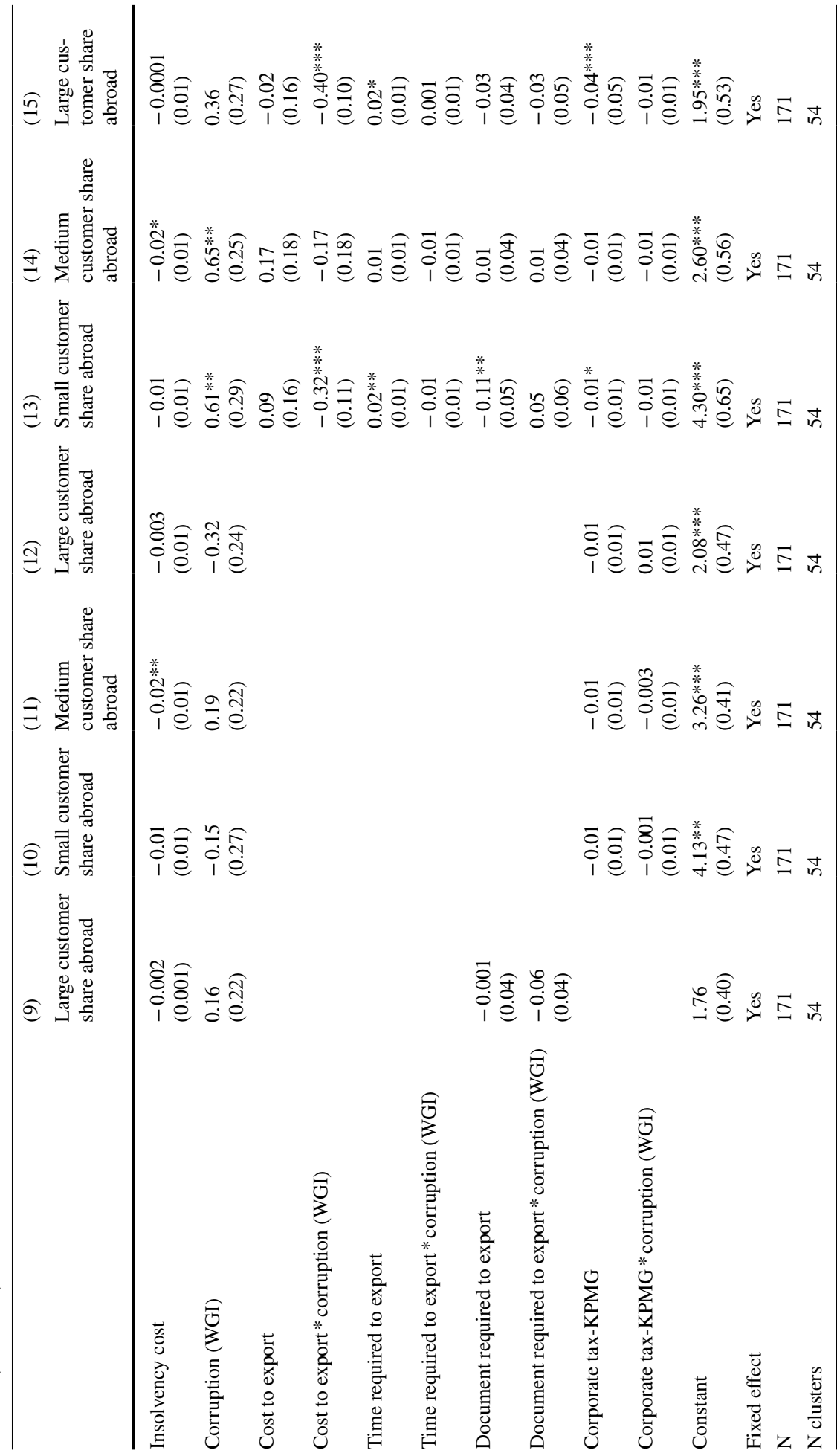




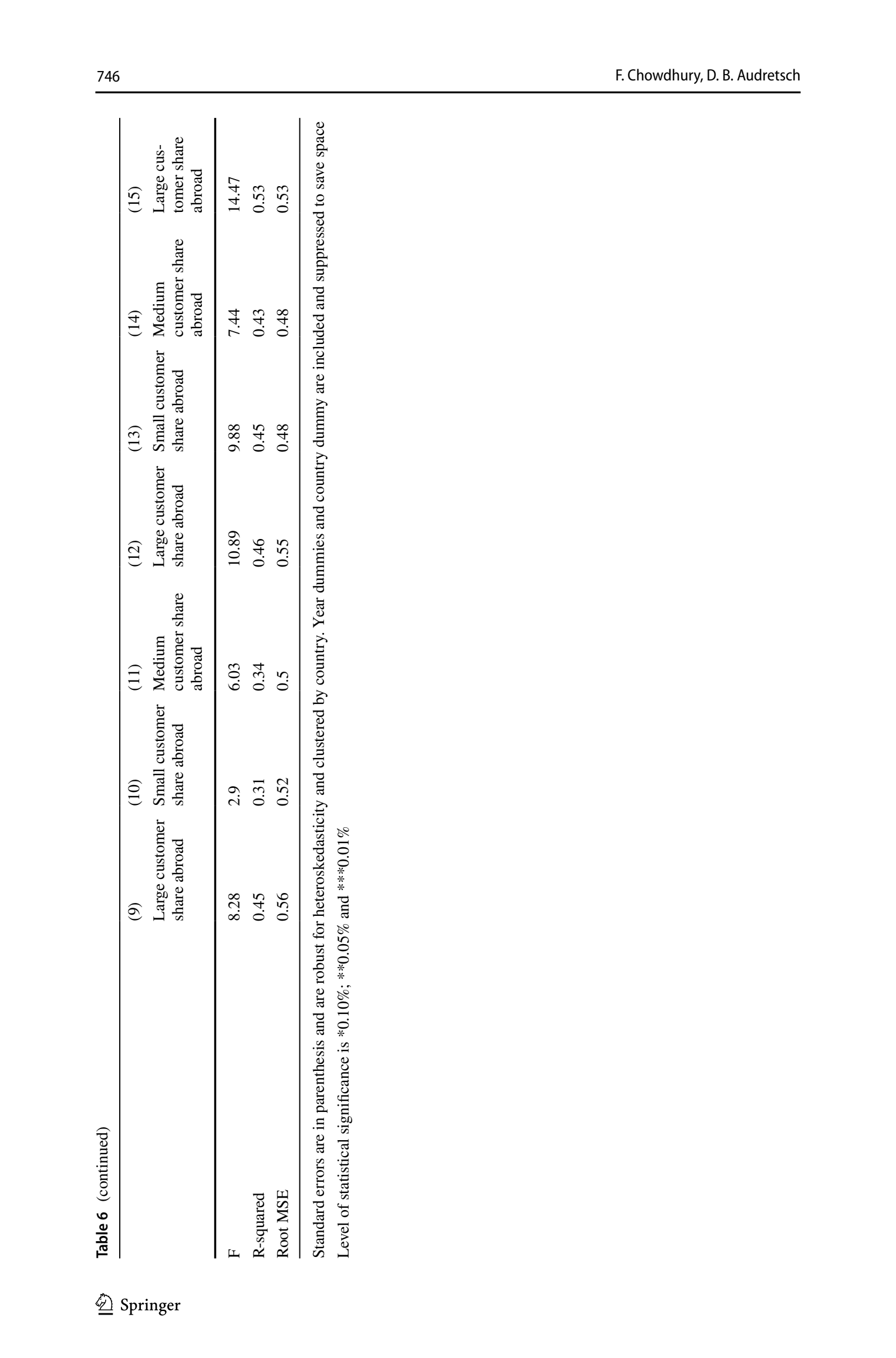




\section{Robustness analysis}

We used two additional corruption measures from the Index of Economic Freedom (Table 5) and another measure of the corporate tax rate from KPMG (Table 6), for robustness checks. We have also run a regression using Transparency International's Corruption Perception Index (CPI) measure. The results are included in Table 8 in Appendix.

In Table 5, similar to the original analysis, all the variables are lagged 1 year. Hypothesis 1 is supported, as the coefficient of interest (corruption) is positive in all cases with varying degrees of significance and some cases not statistically significant. We found partial support for Hypothesis 2, similar to previous results, interestingly, export regulation measures become significant and the corporate tax rate is not significant.

The interactions of corruption and costs associated with exports continue to have a significant negative relationship with all nascent IE firms, regardless of the size. Like the previous results, the time to export and export procedures have no significant effect on small and medium nascent IEs. The interaction between time to export and corruption is significant for large nascent IEs $(\beta=-0.001, p<0.05)$. In specification $13-15$ we present results for the full models. Export costs and corruption interaction have a negative relationship with all nascent IEs.

The results from a robustness check using KPMG tax data are reported in Table 6. The corporate tax rate is a concern for all nascent IEs. The specifications 13-15 in Table 6 presents results for KPMG corporate tax data for all size nascent IEs. These IEs continue to have a negative relationship with corporate tax $(\beta=-0.04, p<0.01)$. In Table 4 , a result related to corporate tax, corruption, and small IEs was negative but not significant, but it is negative and significant using the KPMG tax measure. Results hold consistent in the full model for other measures.

Results in Table 6 for the cost of exports, corruption, and IE remain similar to previous results, still supporting Hypothesis 3 that corruption can be an added cost for nascent IEs. Results related to time requirements, tax rates, and corruption are also consistent with previous results.

\section{Discussion and conclusions}

Policymakers and scholars have an interest in measuring international entrepreneurship within a country. This paper advances the discussion related to the level of international entrepreneurship activity in a country by investigating its relationship with corruption and regulatory measures within a country. Our results underscore the variance between types of regulations and IE level in a country. We examined how regulatory institutions (specifically export and tax regulations) and corruption can directly and jointly influence nascent international entrepreneurs in the home country. In hypothesis 1 , we posited that corruption will have a positive relationship with the home country nascent international entrepreneurship and we find support for our hypothesis. Concerning our hypothesis 2 , we find that not all regulations have a similar impact on nascent home country international entrepreneurship. Regulations that have financial implications have a stronger effect than the regulations with no financial implications. Time and cost-related regulations are important since they put the financial burden. In hypothesis 3, we predicted that corruption will strengthen the positive relationship between home country regulatory environment and home country nascent international entrepreneurship. We find partial support for our hypothesis; the results of this study suggest that the combination of regulations that have financial implications, corruption of home country can have a detrimental impact on the home country's nascent international entrepreneurship. Our results indicate that regulations and corruption have a more nuanced relationship with nascent IEs in the home country. 
Our results show a more complicated relationship between nascent IEs, corruption, and regulations. The negative relationship between cost-related regulations, corruption, and nascent IEs suggest that cost-benefit analysis between investment in the venture and quality of government can have important implications for the nascent IEs in a country. Our results related to tax rate and corrption suggest that IE is not influenced by the tax rate in a high corrupt country. The result might reflect implications for trust on government. In a corrupt country, trust in the government can be limited to none. This lack of trust in government in turn leads to legitimacy problem for the government or government officials. Trust and legitimacy help governments to establish social norms and boundaries. Trust in government is also important in establishing government effectiveness that the tax payers' funds will be used appropriately. These norms, boundaries, and government effectiveness create a predictable environment for entrepreneurs. Therefore, if the goal for the policymakers is to promote international entrepreneurial activity in a country, then the investment should be made to create such an environment.

Researchers and policymakers have considerable interest in increasing entrepreneurship. They continuously examine the role of institutions that influences a wide variety of economic activities. The result of the article might shed light on the question of "how, why, and when do entrepreneurial firms discover and exploit opportunities outside their home country?" (Zahra and Garvis 2000). Future studies may also explore how the relationship between regulatory environment, corruption, and nascent IEs change as a country transitions through various stages of development such as factor- and efficiency-driven stages as these relationships can be an important and decisive factor in these economies.

\subsection{Managerial Implications}

The results of our study have implications are both policymakers and firm managers. Policymakers are interested in adopting policies that generate entrepreneurial activity while entrepreneurs are interested in creating and sustaining their businesses. Both parties can work together to create an environment beneficial for both parties. Since entrepreneurs tend to lack the necessary political capital and financial resources to effectively engage in the political environment, policymakers may adapt venues that allow entrepreneurs to engage more effectively in the political environment and maintain the venture's resources.

Acknowledgements We thank Farzana Chowdhury's Dissertation committee for their comments on an early version of the paper, as well as participants at the Eastern Academy of Management and Global Strategy and Emerging Market conferences.

\section{Compliance with ethical standards}

Conflict of interest None of the authors have any conflict of interest.

Open Access This article is licensed under a Creative Commons Attribution 4.0 International License, which permits use, sharing, adaptation, distribution and reproduction in any medium or format, as long as you give appropriate credit to the original author(s) and the source, provide a link to the Creative Commons licence, and indicate if changes were made. The images or other third party material in this article are included in the article's Creative Commons licence, unless indicated otherwise in a credit line to the material. If material is not included in the article's Creative Commons licence and your intended use is not permitted by statutory regulation or exceeds the permitted use, you will need to obtain permission directly from the copyright holder. To view a copy of this licence, visit http://creativecommons.org/licenses/by/4.0/. 


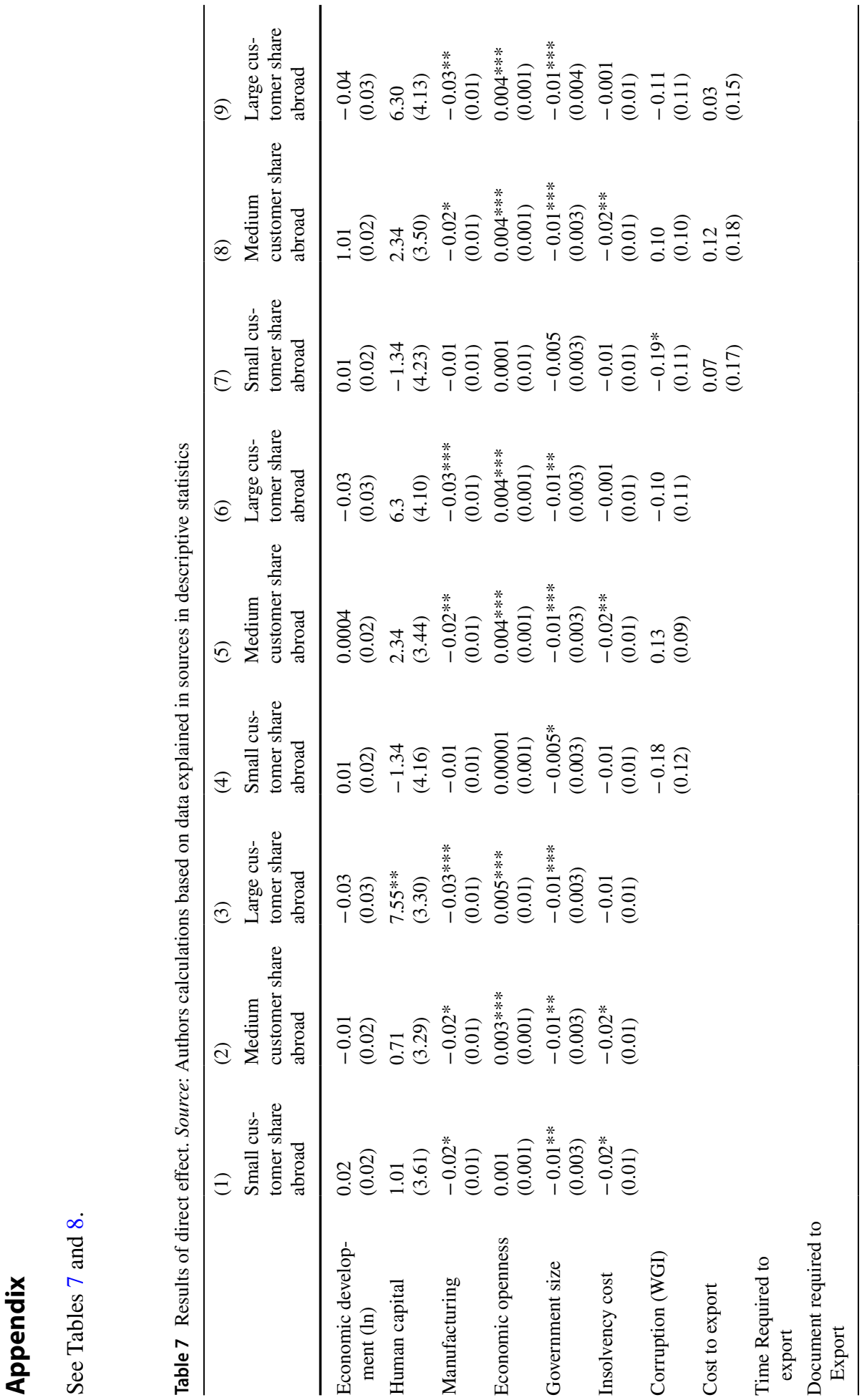




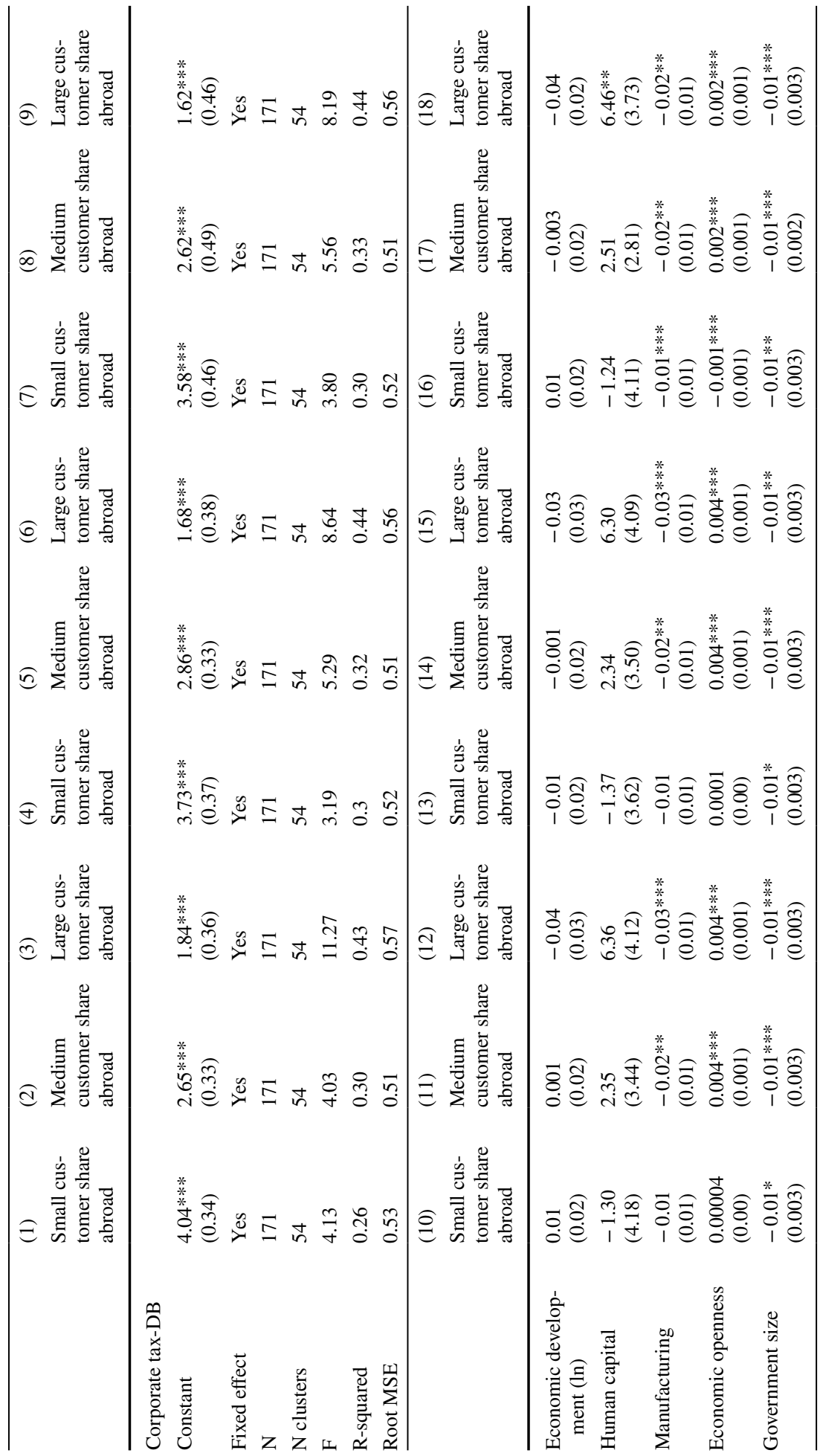




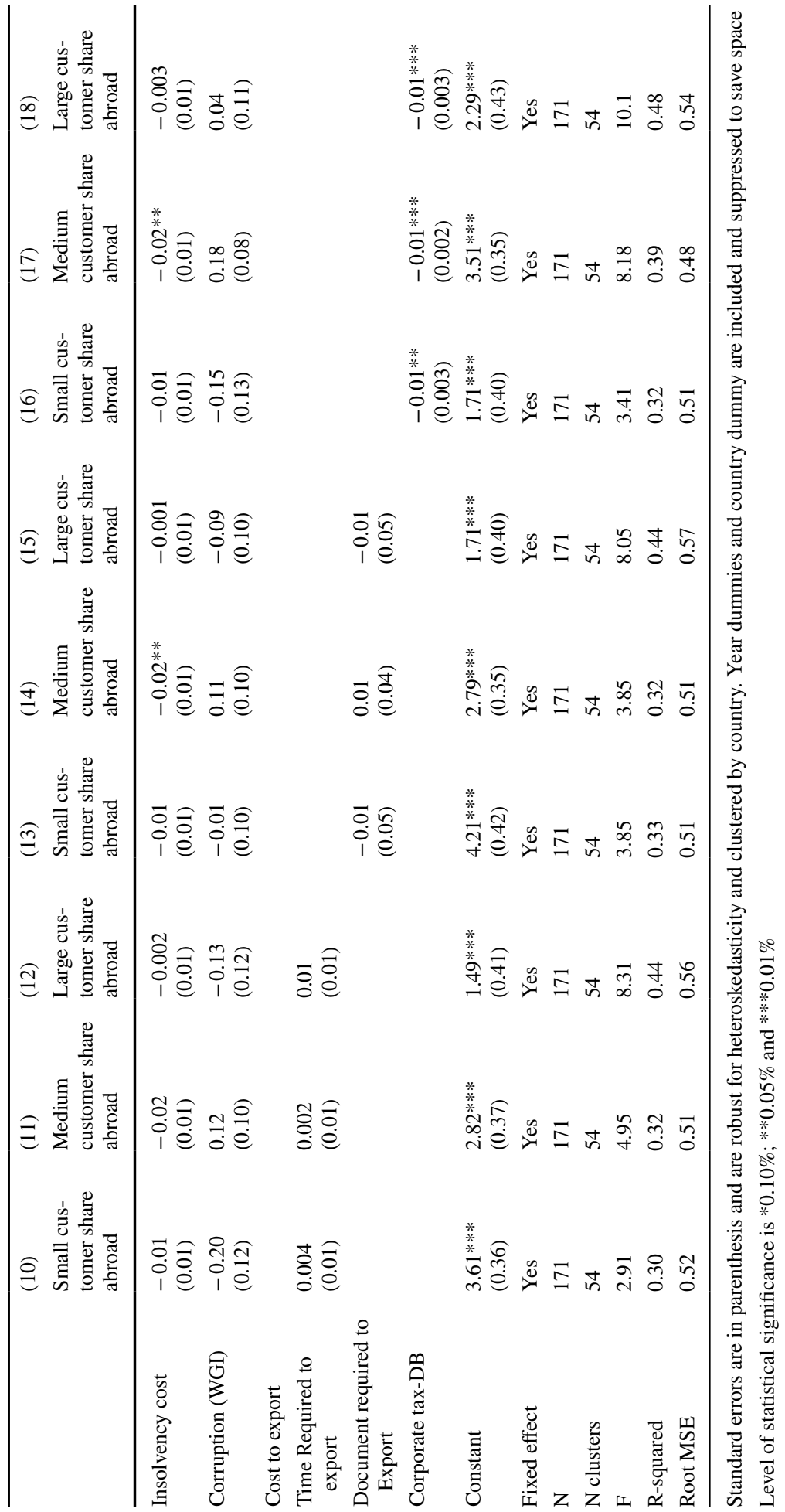




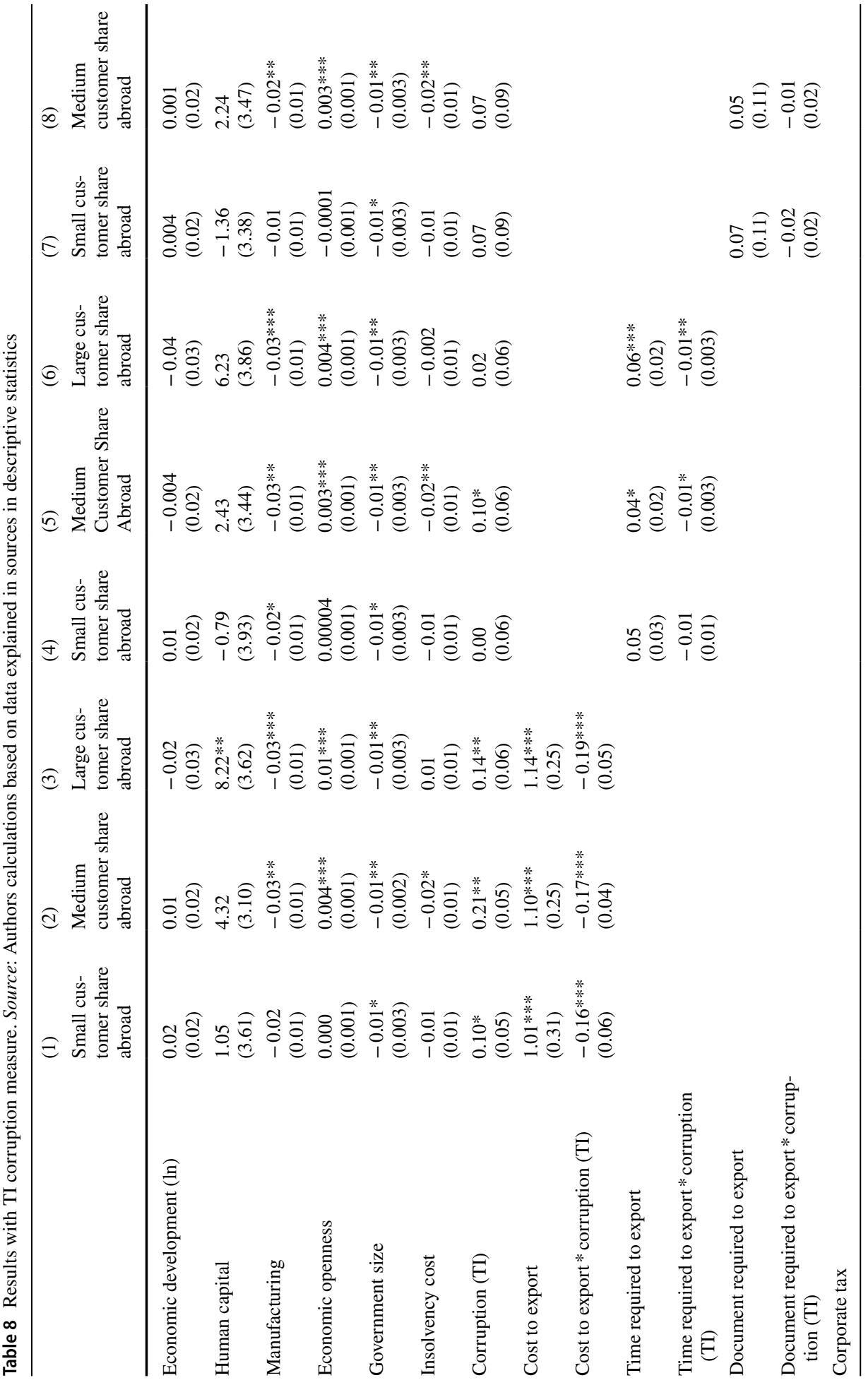




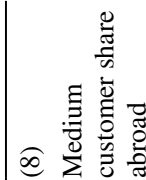

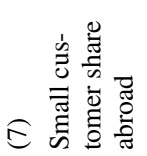

宅

e

营

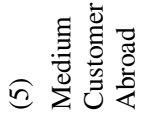

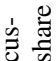

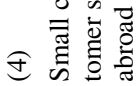

它密

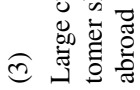

$\frac{\mathscr{T}}{5}$

灵苛

तิ $\sum^{0} \bar{\partial}$

它产

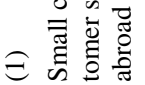

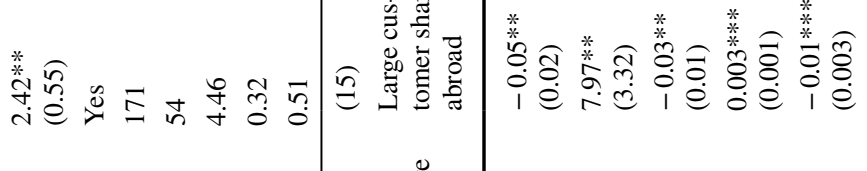

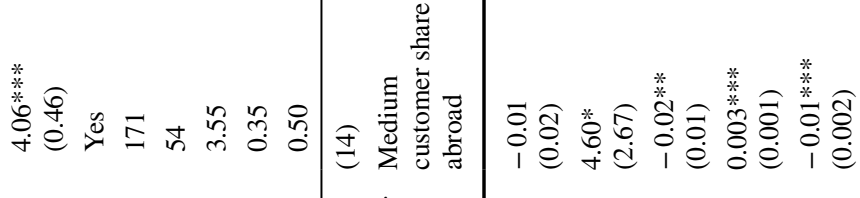

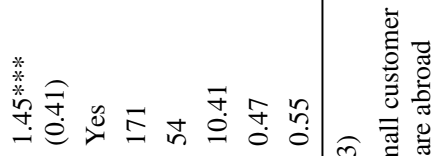

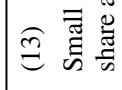

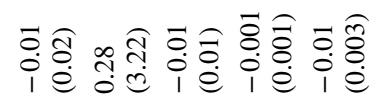

离

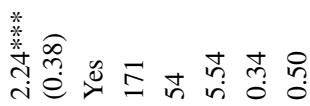

తิ

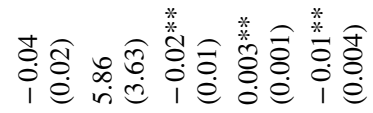

๙ै.

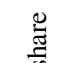

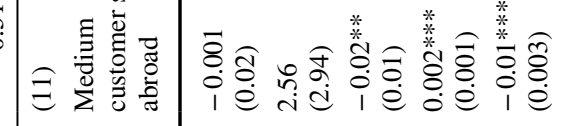

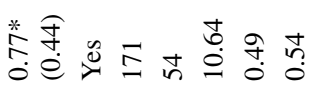

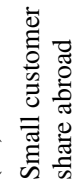

***

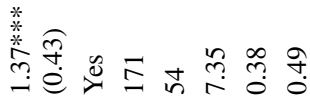

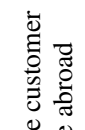

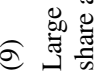

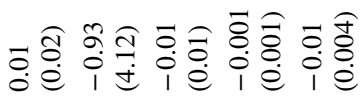

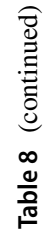

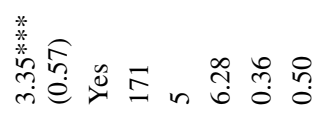

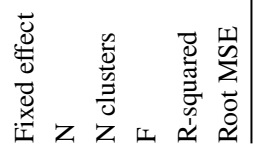

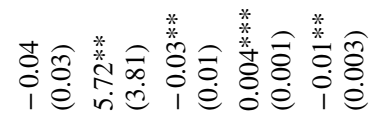

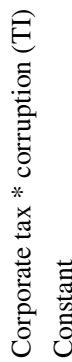




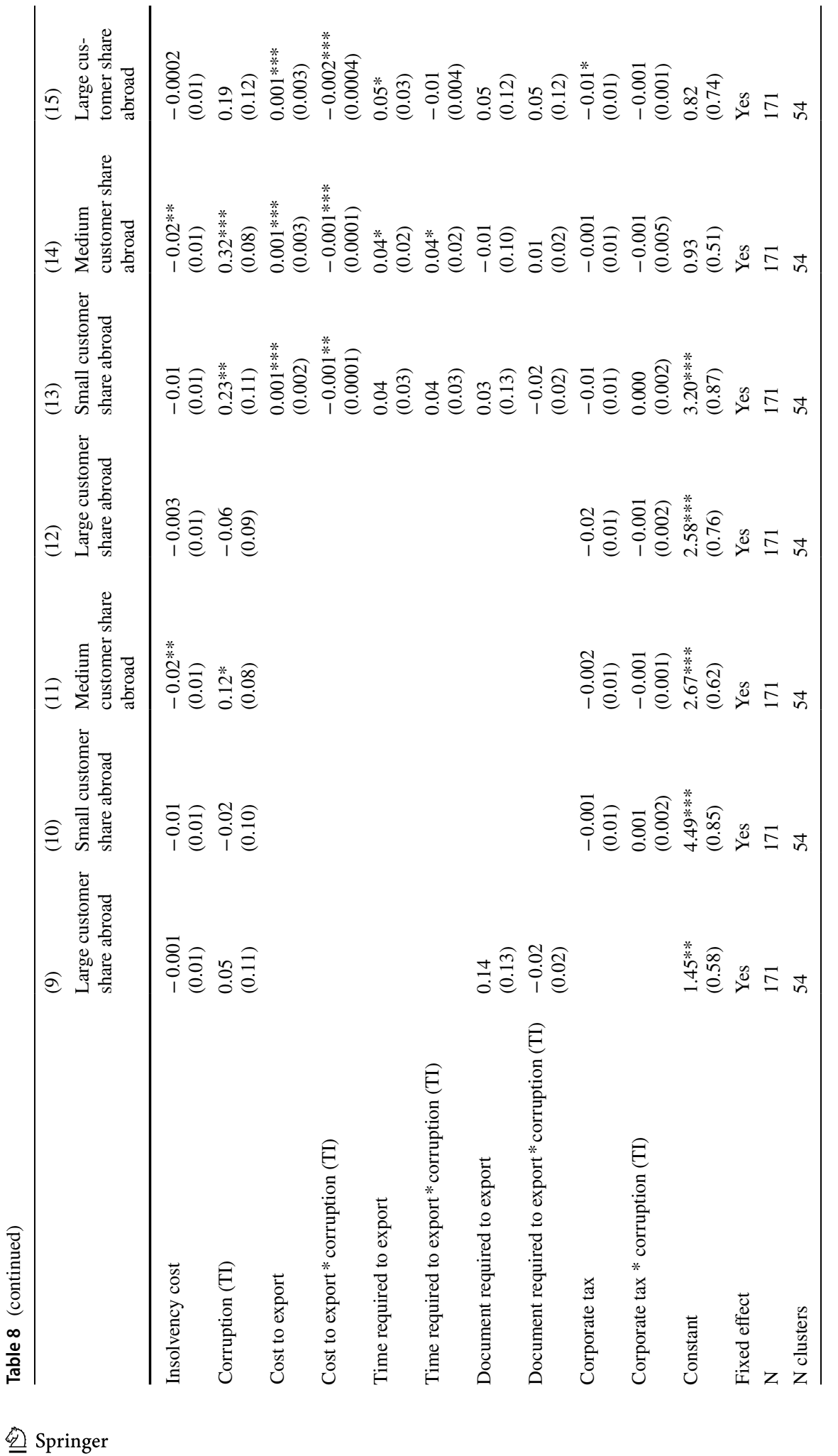


Do corruption and regulations matter for home country nascent...

755

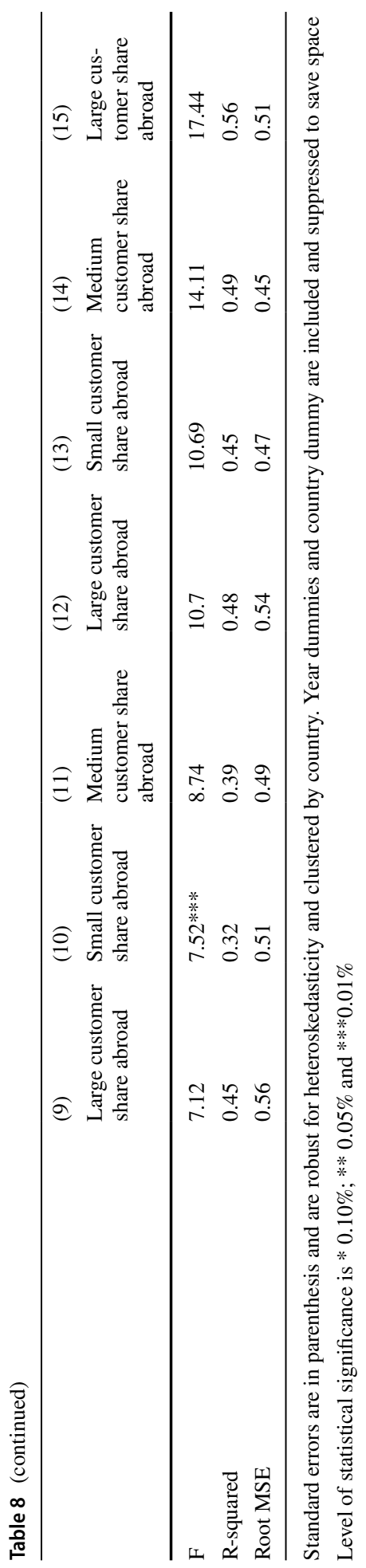

Springer 


\section{References}

Aghion, P., Alesina, A., \& Trebbi, F. (2004). Endogenous political institutions. The Quarterly Journal of Economics, 119(2), 565-611.

Alesina, A., Devleeschauwer, A., Easterly, W., Kurlat, S., \& Wacziarg, R. (2003). Fractionalization. Journal of Economic growth, 8(2), 155-194.

Anokhin, S., \& Schulze, W. S. (2009). Entrepreneurship, innovation, and corruption. Journal of Business Venturing, 24(5), 465-476.

Autio, E., George, G., \& Alexy, O. (2011). International entrepreneurship and capability developmentQualitative evidence and future research directions. Entrepreneurship Theory and Practice, 35(1), 11-37.

Autio, E., Sapienza, H. J., \& Almeida, J. G. (2000). Effects of age at entry, knowledge intensity, and imitability on international growth. Academy of Management Journal, 43(5), 909-924.

Barney, J. (1991). Firm resources and sustained competitive advantage. Journal of Management, 17(1), 99-120.

Barro, R. J. (2000). Rule of law, democracy and economic performance, chapter 2. In G. P. O'Driscoll Jr., K. R. Holmes, \& M. Kirkpatrick (Eds.), 2000 Index of economic freedom. Available at www.heritage. org.

Baumol, W. J. (1990). Entrepreneurship: Productive, unproductive, and destructive. Journal of Political Economy, 98, 893-921.

Baumol, W. J., \& Strom, R. J. (2007). Entrepreneurship and economic growth. Strategic Entrepreneurship Journal, 1(3-4), 233-237.

Belitski, M., Chowdhury, F., \& Desai, S. (2016). Taxes, corruption, and entry. Small Business Economics, 47(1), 201-216.

Berger, Allen, DeYoung, Rober, Genay, Hesna, \& Udell, Gregory. (2000). Globalization of financial institutions: Evidence from cross-border banking performance. Brookings Wharton Papers on Financial Services, 3, 23-125.

Boddewyn, J. J., \& Brewer, T. (1994). International-business political behavior: New theoretical directions. Academy of Management Review, 19, 119-144.

Boettke, P. J., \& Coyne, C. J. (2003). Entrepreneurship and development: Cause or consequence? Advances in Austrian Economics, 6, 67-87.

Bowen, H. P., \& De Clercq, D. (2008). Institutional context and the allocation of entrepreneurial effort. Journal of International Business Studies, 39(4), 747-767.

Calof, J. L., \& Beamish, P. W. (1995). Adapting to foreign markets: Explaining internationalization. International Business Review, 4(2), 115-131.

Cantwell, J., Dunning, J. H., \& Lundan, S. M. (2010). An evolutionary approach to understanding international business activity: The co-evolution of MNEs and the institutional environment. Journal of International Business Studies, 41(4), 567-586.

Carbo, S., Kane, Edward, \& Rodriguez, Francisco. (2008). Evidence of differences in the effectiveness of safety-net management in European union countries. Journal of Financial Services Research, 34, 151-176.

Carree, M., Van Stel, A., Thurik, R., \& Wennekers, S. (2002). Economic development and business ownership: An analysis using data of 23 OECD countries in the period 1976-1996. Small Business Economics, 19(3), 271-290.

Chafuen, A., \& Guzman, E. (2000). Economic freedom and corruption. Index of Economic Freedom, 2000, 51-63.

Chowdhury, F., Audretsch, D. B., \& Belitski, M. (2019). Institutions and entrepreneurship quality. Entrepreneurship Theory and Practice, 43(1), 51-81.

Cooper, R. S. (2003). Purpose and performance of the Small Business Innovation Research (SBIR) program. Small Business Economics, 20(2), 137-151.

Coyne, C. J. (2008). After war: The political economy of exporting democracy. Stanford, CA: Stanford University Press.

Cuervo-Cazurra, A. (2008). Better the devil you don't know: Types of corruption and FDI in transition economies. Journal of International Management, 14(1), 12-27.

Cuervo-Cazurra, A., \& Ramamurti, R. (2017). Home country underdevelopment and internationalization. Competitiveness Review: An International Business Journal, 27, 217-230.

Cui, L., \& Jiang, F. (2010). Behind ownership decision of Chinese outward FDI: Resources and institutions. Asia Pacific Journal of Management, 27(4), 751-774.

Cumming, D. J., Grilli, L., \& Murtinu, S. (2017). Governmental and independent venture capital investments in Europe: A firm-level performance analysis. Journal of Corporate Finance, 42(C), 439-459. 
Davidsson, P., \& Honig, B. (2003). The role of social and human capital among nascent entrepreneurs. Journal of Business Venturing, 18(3), 301-331.

DiMaggio, P. J., \& Powell, W. W. (1983). The iron cage revisited: Institutional isomorphism and collective rationality in organizational fields. American Sociological Review, 48, 147-160.

DiMaggio, P., \& Powell, W. (1991). Introduction. In W. Powell \& P. DiMaggio (Eds.), The new institutionalism in organizational analysis (pp. 1-38). Chicago: University of Chicago Press.

Dimitratos, P., Voudouris, I., Plakoyiannaki, E., \& Nakos, G. (2012). International entrepreneurial cultureToward a comprehensive opportunity-based operationalization of international entrepreneurship. International Business Review, 21(4), 708-721.

Djankov, S., La Porta, R., Lopez-de-Silanes, F., \& Shleifer, A. (2002). The regulation of entry. The Quarterly Journal of Economics, 117(1), 1-37.

Dunning, J. H., \& Lundan, S. M. (2008). Institutions and the OLI paradigm of the multinational enterprise. Asia Pacific Journal of Management, 25(4), 573-593.

Erramilli, M. K., Agarwal, S., \& Kim, S. S. (1997). Are firm-specific advantages location-specific too? Journal of International Business Studies, 28(4), 735-757.

Estrin, S., Korosteleva, J., \& Mickiewicz, T. (2013). Which institutions encourage entrepreneurial growth aspirations? Journal of Business Venturing, 28(4), 564-580.

Fernández, Z., \& Nieto, M. J. (2006). Impact of ownership on the international involvement of SMEs. Journal of International Business Studies, 37(3), 340-351.

Filatotchev, I., \& Piesse, J. (2009). R\&D, internationalization and growth of newly listed firms: European evidence. Journal of International Business Studies, 40(8), 1260-1276.

Fritsch, M., \& Schroeter, A. (2011). Why does the effect of new business formation differ across regions? Small Business Economics, 36(4), 383-400.

Glaeser, E. L., \& Saks, R. E. (2006). Corruption in America. Journal of Public Economics, 90(6-7), 1053-1072.

Grilo, I., \& Thurik, R. (2005). Latent and actual entrepreneurship in Europe and the US: Some recent developments. The International Entrepreneurship and Management Journal, 1(4), 441-459.

Helmke, G., \& Levitsky, S. (2004). Informal institutions and comparative politics: A research agenda. Perspectives on Politics, 2(4), 725-740.

Hessels J. (2008). International entrepreneurship: Value creation across national borders (No. EPS-2008-144-ORG).

Hoskisson, R. E., Hitt, M. A., Ireland, R. D., \& Harrison, J. S. (2012). Competing for advantage. Boston: Cengage Learning.

Jain, A. K. (2001). Corruption: A review. Journal of Economic Surveys, 15(1), 71-121.

Johnson, S., McMillan, J., \& Woodruff, C. (2002). Property rights and finance. American Economic Review, 92(5), 1335-1356.

Kane, E. J. (2000). Incentives for banking megamergers: What motives might regulators infer from eventstudy evidence? Journal of Money, Credit and Banking, 32, 671-705.

Kane, E. J. (2009). Extracting nontransparent safety net subsidies by strategically expanding and contracting a financial institution's accounting balance sheet. Journal of Financial Services Research, 36, $161-168$.

Kaufmann, D., Kraay, A., Mastruzzi, M. (2009). Governance matters VIII: Aggregate and individual governance indicators 1996-2008.

Keefer, P. (1996). Protection against a capricious state: French investment and Spanish railroads, 18451875. Journal of Economic History, 56, 170-192.

Kim, P. H., \& Li, M. (2014). Injecting demand through spillovers: Foreign direct investment, domestic socio-political conditions, and host-country entrepreneurial activity. Journal of Business Venturing, 29(2), 210-231.

Klapper, L., Laeven, L., \& Rajan, R. (2006). Entry regulation as a barrier to entrepreneurship. Journal of Financial Economics, 82(3), 591-629.

La Porta, R., Lopez-de-Silanes, F., Shleifer, A., \& Vishny, R. (1999). The quality of government. The Journal of Law, Economics, and Organization, 15(1), 222-279.

Lawton, T. C., Doh, J. P., \& Rajwani, T. (2014). Aligning for advantage: Competitive strategies for the political and social arenas. Oxford: Oxford University Press.

Li, J., Moy, J., Lam, K., \& Chu, W. C. (2008). Institutional pillars and corruption at the societal level. Journal of Business Ethics, 83(2), 327-339.

Lockett, A., Wright, M., Burrows, A., Scholes, L., \& Paton, D. (2008). The export intensity of venture capital backed companies. Small Business Economics, 31(1), 39-58.

Lu, J. W., \& Beamish, P. W. (2006). Partnering strategies and performance of SMEs' international joint ventures. Journal of Business Venturing, 21(4), 461-486. 
Luo, Y., Xue, Q., \& Han, B. (2010). How emerging market governments promote outward FDI: Experience from China. Journal of World Business, 45, 68-79.

Martens, M. L., Jennings, J. E., \& Jennings, P. D. (2007). Do the stories they tell get them the money they need? The role of entrepreneurial narratives in resource acquisition. Academy of Management Journal, 50(5), 1107-1132.

McMullen, J. S., Bagby, D., \& Palich, L. E. (2008). Economic freedom and the motivation to engage in entrepreneurial action. Entrepreneurship Theory and Practice, 32(5), 875-895.

McMullen, J. S., \& Shepherd, D. A. (2006). Entrepreneurial action and the role of uncertainty in the theory of the entrepreneur. Academy of Management Review, 31(1), 132-152.

Méon, P. G., \& Sekkat, K. (2005). Does corruption grease or sand the wheels of growth? Public Choice, 122(1-2), 69-97.

Méon, P. G., \& Weill, L. (2010). Is corruption an efficient grease? World Development, 38(3), 244-259.

Meyer, K. E., Estrin, S., Bhaumik, S. K., \& Peng, M. W. (2009). Institutions, resources, and entry strategies in emerging economies. Strategic Management Journal, 30(1), 61-80.

Mo, P. H. (2001). Corruption and economic growth. Journal of Comparative Economics, 29(1), 66-79.

North, D. (1990). Institutions, institutional change and economic performance. New York: Cambridge University Press.

North, D. C. (1991). Institutions. Journal of Economic Perspectives, 5(1), 97-112.

OECD. (2002). Regulatory policies in OECD countries: From interventionism to regulatory governance. Paris: OECD.

Oliver, C. (1991). Strategic responses to institutional processes. Academy of Management Review, 16(1), 145-179.

Pejovich, S. (1999). The effects of the interaction of formal and informal institutions on social stability and economic development. Journal of Markets and Morality, 2(2), 164-181.

Peng, M. W., Sun, S. L., Pinkham, B., \& Chen, H. (2009). The institution-based view as a third leg for a strategy tripod. Academy of Management Perspectives, 23(3), 63-81.

Qian, G. (2002). Multinationality, product diversification, and profitability of emerging U.S. small- and medium sized enterprises. Journal of Business Venturing, 17, 611-633.

Reynolds, P. D., Bygrave, B., \& Hay, M. (2003). Global entrepreneurship monitor report. Kansas City, MO: E.M. Kauffmann Foundation.

Rodriguez, P., Siegel, D. S., Hillman, A., \& Eden, L. (2006). Three lenses on the multinational enterprise: Politics, corruption, and corporate social responsibility. Journal of International Business Studies, 37(6), 733-746.

Rodriguez, P., Uhlenbruck, K., \& Eden, L. (2005). Government corruption and the entry strategies of multinationals. Academy of Management Review, 30(2), 383-396.

Rose-Ackerman, S. (1999). Corruption and government: Causes, consequences, and reform. Cambridge: Cambridge University Press.

Rose-Ackerman, S. (2007). International handbook on the economics of corruption. Cheltenham: Edward Elgar Publishing.

Schwens, C., Zapkau, F. B., Bierwerth, M., Isidor, R., Knight, G., \& Kabst, R. (2017). International entrepreneurship: A meta-analysis on the internationalization and performance relationship. Entrepreneurship Theory and Practice. https://doi.org/10.1111/etap.12280.

Scott, W. R. (2001). Institutions and organizations. Thousand Oaks, CA: Sage Publications Inc.

Scott, W. R. (2014). Institutions and organizations (4th ed.). Thousand Oaks, CA: Sage Publications.

Shleifer, A., \& Vishny, R. W. (1993). Corruption. The Quarterly Journal of Economics, 108(3), 599-617.

Stigler, G. J. (1971). The economic theory of regulation. Bell Journal of Economics, 2(1), 3-21.

Sugden, R. (1986). The economics of rights, cooperation, and welfare. New York: Basil Blackwell.

Tanzi, V. (1998). Corruption around the world: Causes, consequences, scope, and cures. IMF Staff Papers, 45(4), 559-594.

Tanzi, V., \& Davoodi, H. (2001). Corruption, growth, and public finances. In A. K. Jain (Ed.), The political economy of corruption (pp. 101-122). London: Routledge.

Treisman, D. (2000). The causes of corruption: A cross-national study. Journal of Public Economics, 76(3), 399-457.

Westhead, P., Wright, M., \& Ucbasaran, D. (2001). The internationalization of new and small firms: A resource-based view. Journal of Business Venturing, 16(4), 333-358.

Williamson, O. E. (2000). The new institutional economics: Taking stock, looking ahead. Journal of Economic Literature, 38(3), 595-613.

Witt, M. A., \& Lewin, A. Y. (2007). Outward foreign direct investment as escape response to home country institutional constraints. Journal of International Business Studies, 38(4), 579-594.

World Bank. (2003). Doing business in 2004: Understanding regulation. Washington, DC: World Bank. 
Yamakawa, Y., Khavul, S., Peng, M. W., \& Deeds, D. L. (2013). Venturing from emerging economies. Strategic Entrepreneurship Journal, 7(3), 181-196.

Yiu, D. W., Lau, C., \& Bruton, G. D. (2007). International venturing by emerging economy firms: The effects of firm capabilities, home country networks, and corporate entrepreneurship. Journal of International Business Studies, 38(4), 519-540.

Zahra, S. A., \& Garvis, D. M. (2000). International corporate entrepreneurship and firm performance: The moderating effect of international environmental hostility. Journal of Business Venturing, 15(5-6), 469-492.

Publisher's Note Springer Nature remains neutral with regard to jurisdictional claims in published maps and institutional affiliations. 